\title{
SURFACE MAGNETIC FIELD NOISE MEASUREMENTS AT GENEVA MINE
}

J. W. Adams

W. D. Bensema

N. C. Tomoeda

Electromagnetics Division Institute for Basic Standards National Bureau of Standards Boulder, Colorado 80302

June 1974

Prepared for:

U. S. Bureau of Mines

United States Department of the Interior

Pittsburg, Pennsylvania 15222

Working Fund Agreement HO 133005 


\section{NBSIR 74-369}

\section{SURFACE MAGNETIC FIELD NOISE MEASUREMENTS AT GENEVA MINE}

J. W. Adams

W. D. Bensema

N. C. Tomoeda

Electromagnetics Division

Institute for Basic Standards

National Bureau of Standards

Boulder, Colorado 80302

The views and conclusions contained

in this document should not be

interpreted as necessarily representing the official policies or recommendations of the Interior Department's Bureau of Mines of the U. S. Government.

June 1974

Prepared for

U. S. Bureau of Mines

United States Department of the Interior

Pittsburg, Pennsylvania 15222

Working Fund Agreement HO 133005

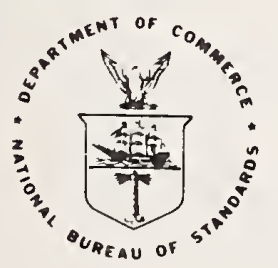

U.S. DEPARTMENT OF COMMERCE. Frederick B. Dent, Secretary 


\section{FOREWORD}

This report was prepared by the National Bureau of Standards, Boulder, Colorado, under USBM Contract No. HO 133005. The contract was initiated under the Coal Mine Health and Safety Research Program. It was administered under the technical direction of the Pittsburgh Mining and Safety Research Center with Mr. Howard Parkinson and Mr. Harry Dobrowski acting as the technical project officers.

This report is a summary of the work completed as part of this contract during the period June 1973 to June 1974. This report was submitted by the authors in september, 1974. 


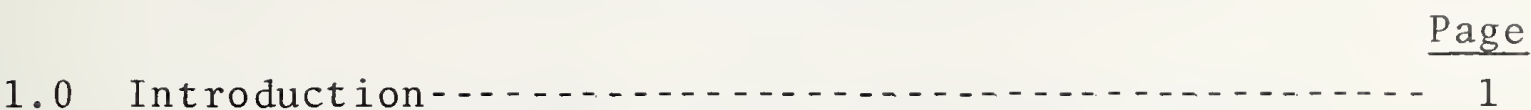

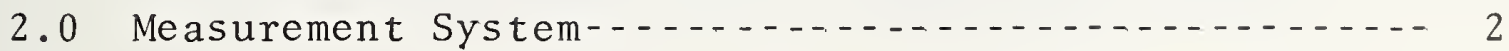

3.0 Earth-Ionosphere Waveguide Effect on Propagated

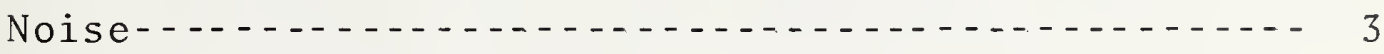

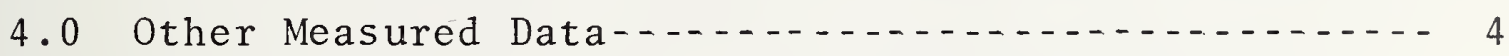

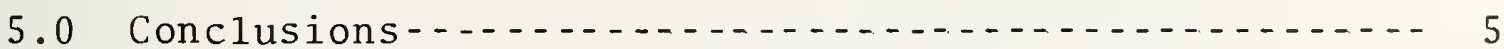

6.0 Recommendations -............................... 5

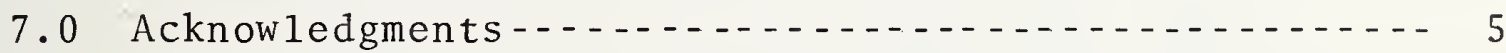

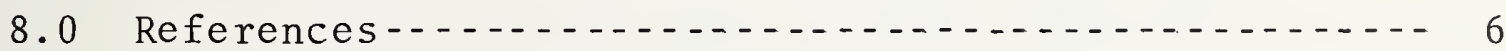

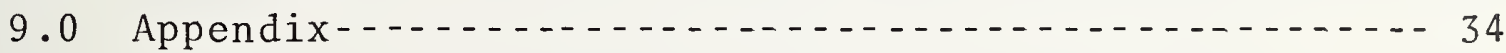

\section{LIST OF FIGURES}

Figure 1. Field recording system-.................. 7

Figure 2a. Digitizing part of data processing system---- 8

Figure 2b. Fast-Fourier transform part of data processing system-....................... 8

Figure 3. Spectrum of the horizontal, E-W component-..- 9

Figure 4. Spectrum of the horizonta1, N-S component--.- 10

Figure 5. Spectrum of magnetic field strength vs. time-- 11

Figure 6. Spectrum of magnetic field strength vs. time-- 12

Figure 7. Map of surface over Geneva Coal Mine-...-..- 13

Figure 8. Spectrum of surface EM noise at Lila Flats over Geneva Mine........................... 14

Figure 9. Spectrum of surface EM noise, north side of

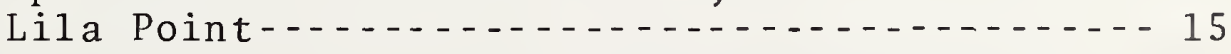

Figure 10. $10 \mathrm{kHz}$ spectrum of surface EM noise at Lila

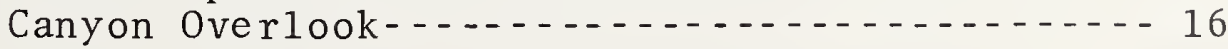


Figure 11. $10 \mathrm{kHz}$ spectrum of surface EM noise at Lila

Canyon Overlook-.......................... 17

Figure 12. $10 \mathrm{kHz}$ spectrum of surface EM noise at Lila

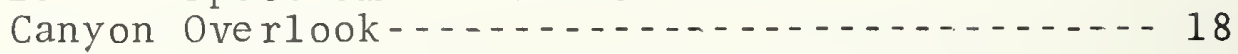

Figure 13. $10 \mathrm{kHz}$ spectrum of surface noise at Lila

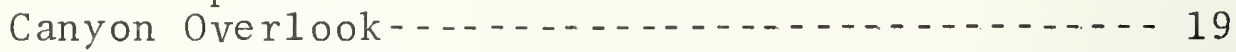

Figure 14. $10 \mathrm{kHz}$ spectrum of surface noise at Lila

Canyon Overlook-.................... 20

Figure 15. $10 \mathrm{kHz}$ spectrum of surface noise at Lila

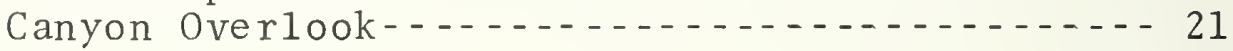

Figure 16. $10 \mathrm{kHz}$ spectrum of surface EM noise at Lila

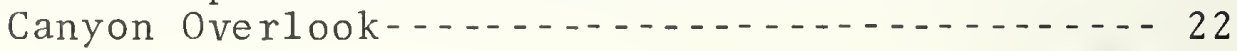

Figure 17. $10 \mathrm{kHz}$ spectrum of surface EM noise at Lila

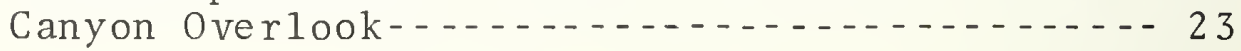

Figure 18. $10 \mathrm{kHz}$ spectrum of surface EM noise at Lila

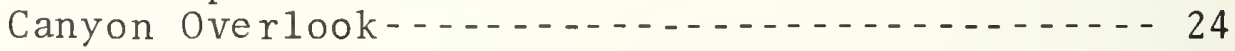

Figure $19.3 \mathrm{kHz}$ spectrum of surface EM noise at Lila

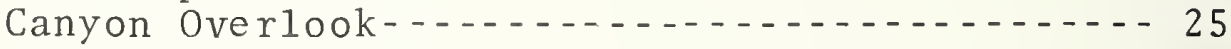

Figure $20.3 \mathrm{kHz}$ spectrum of surface EM noise at Lila

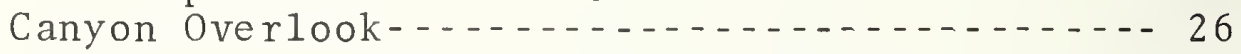

Figure 21. $3 \mathrm{kHz}$ spectrum of surface EM noise at Lila

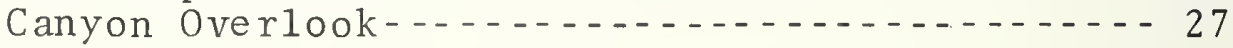

Figure 22. $3 \mathrm{kHz}$ spectrum of surface EM noise at Lila

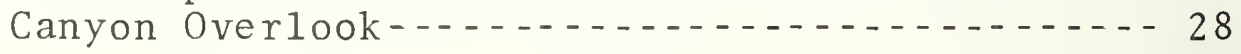

Figure $23.3 \mathrm{kHz}$ spectrum of surface EM noise at Lila

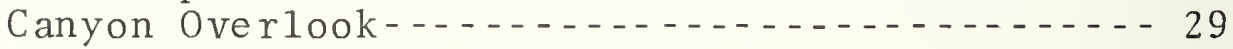

Figure $24.3 \mathrm{kHz}$ spectrum of surface EM noise at Lila

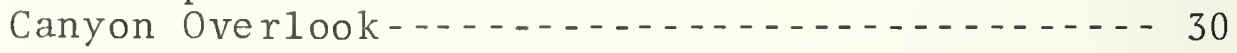

Figure $25.3 \mathrm{kHz}$ spectrum of surface EM noise at Lila

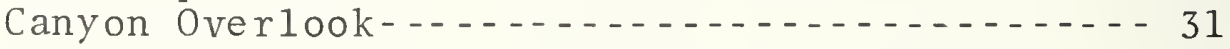

Figure 26. $3 \mathrm{kHz}$ spectrum of surface EM noise at Lila

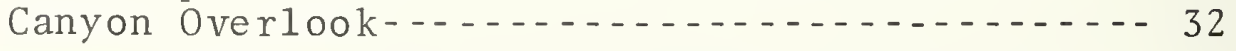

Figure 27. $3 \mathrm{kHz}$ spectrum of surface EM noise at Lila

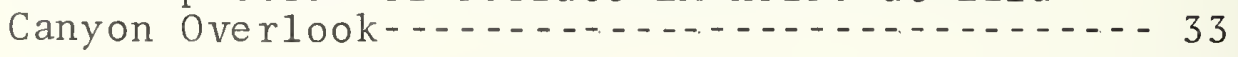




\section{SURFACE MAGNETIC FIELD NOISE MEASUREMENTS}

AT GENEVA MINE

by

J.W. Adams, W.D. Bensema, N.C. Tomoeda

Measurements of surface magnetic field noise were made at various locations over the Geneva Coal Mine near Price, Utah, on June 12, 1973. The locations selected were on the surface over emergency locator beacons underground at depths between 350 meters $(1150 \mathrm{ft.})$ and 488 meters $(1600 \mathrm{ft}$.$) . The surface$ terrain where these measurements were made was mountainous, and access was difficult. There were no power 1 ines within several miles, and the weather was clear; therefore, the magnetic noise levels were about as low as will normally occur.

Results of measurements of distant sferics indicate rather sharp cutoff frequencies below which broadband, impulsive noise is attenuated. The mechanism of propagation for this noise above the daytime cutoff frequency of $3500 \mathrm{~Hz}$ and the nighttime cutoff frequency of $1700 \mathrm{~Hz}$ is deduced to be a waveguide formed by the $D$ or E layers of ionosphere as an upper plane and the earth as a lower plane.

The measurement systems used are similar to those used earlier. The technique is to record broadband, analog signals, digitize the data, and use a fastFourier transform to obtain spectral plots. This technique is novel in that it can measure simultaneously all magnetic field energy within a limited portion of the spectrum for a limited time, and, after processing, reproduce the events occurring in that time interval in great detail.

Key words: Earth-ionosphere waveguide; electromagnetic noise; EMI measurement technique; sferic interference.

\subsection{Introduction}

Magnetic field strength measurements were made on June 12 , 1973, over the Geneva Coal Mine in the Book Cliff Mountain Range east of Price, Utah. The locations selected were on the surface over emergency locator beacons underground at 
depths between 350 meters (1150 ft.) and 488 meters (1600 ft.). The surface terrain where these measurements were made was mountainous, and access was difficult. There were no power lines within several miles, and the weather was clear; therefore, the magnetic noise levels were about as low as willnormal1y occur.

The primary purpose of the measurements was to determine surface magnetic field noise levels so that performance of emergency subsurface locator beacons of the U.S. Bureau of Mines could be better predicted. These emergency locator beacons are located many hundreds of feet underground and when activated, generate magnetic fields in a pulsed-carrier, on-off mode for signaling to the surface, usually in emergency situations. They operate at frequencies below $3 \mathrm{kHz}$ where signal attenuation through the earth is relatively low; however, the beacon signals are greatly at tenuated by various effects, and surface noise becomes a limiting factor.

\subsection{Measurement System}

The block diagram of the field recording measurement system is shown in figure 1. It consists of a balanced, shielded loop antenna, balun, filter, and analog tape recorder. Later in the laboratory, the analog signal is filtered, digitized, fast Fourier transformed, and plotted on microfilm. See figure 2 for the laboratory processing system. This gives an output plot of one component of absolute magnetic field strength versus frequency--a spectral plot. The transform may be repeated to allow three-dimensional plots, where time is the additional variable.

This system is described in more detail in the Robena Mine report [1]. 


\subsection{Earth-Ionosphere Waveguide Effect on Propagated Noise}

During the time the measurements were being made, there were no visible thunderstorms or clouds anywhere in sight, and hence, the atmospheric noise was 1 argely that propagated from distant sources. During daylight, strong sferics were present, primarily above $3500 \mathrm{~Hz}$, as shown in figure 3. At night, sferics came in above $1700 \mathrm{~Hz}$, as shown in figure 4 . A three-dimensional view given in figure 5 shows more detail of the daytime structure. A similar plot in figure 6 shows the nighttime structure. Note the $2500 \mathrm{~Hz}$ and $1900 \mathrm{~Hz}$ subsurface coal mine beacon signals in figure 5. The $1900 \mathrm{~Hz}$ beacon is almost obscured by the atmospheric noise at night (see figure 6). Notice the sharp cutoff of noise at $1700 \mathrm{~Hz}$ at night and the more gradual cutoff at $3500 \mathrm{~Hz}$ during the day.

Ionospheric effects on radio transmission have been widely studied for years, but these measurements with this new system show some fresh insights into earth-ionosphere waveguide phenomena. A dramatic and sharp increase in attenuation of propagated atmospheric noise at frequencies below the waveguide cutoff frequency (as mentioned above) has been observed. About ten $d B$ of signal-to-noise ratio may be gained by operating at a frequency below the waveguide cutoff frequency rather than above the cutoff, as shown by the one example in figure 6 .

The probable propagation mechanism is a parallel plate waveguide formed by the $D$ or $E$ layers of the ionosphere and the earth. The TE or TM modes are excited between the parallel planes and have a cutoff frequency of

$$
\mathrm{f}_{\mathrm{c}}=\frac{\mathrm{nc}}{2 \mathrm{a}}, \mathrm{n}=1,2, \cdots,
$$

where $c$ is the velocity of light, and a is the spacing between the plates [2]. 


$$
\text { If } a=88 \mathrm{~km}, \mathrm{f}_{\mathrm{c}}=1704 \mathrm{~Hz}, 3408 \mathrm{~Hz}, \ldots \text {. If the } \mathrm{D}
$$

layer is about $50 \mathrm{~km}$ above the earth, and if the $\mathrm{E}$ layer is about $100 \mathrm{~km} \mathrm{high} \mathrm{[3],} \mathrm{the} \mathrm{cutoff} \mathrm{frequencies} \mathrm{calculated} \mathrm{are}$ approximately correct. The height of maximum ionospheric density may vary somewhat, and may not be the exact distance needed for this model. This phenomenon should be further investigated, as it relates directly to what frequencies that should be used for the emergency locator beacons.

\subsection{Other Measured Data}

A map of the surface is shown in figure 7 . Noise at location B1, 463 meters (1520 feet) over the $1900 \mathrm{~Hz}$ beacon, is shown in figure 8 . Noise at location $\mathrm{Cl}, 442$ meters (1450 feet) over a $1700 \mathrm{~Hz}$ beacon, is shown in figure 9 .

Al1 the remaining figures are of noise at location A1, 1150 feet over a $2500 \mathrm{~Hz}$ beacon.

Figures 10 through 18 show spectra of day, twilight, and night noise to $10 \mathrm{kHz}$. Figure 13 shows a distant sferic.

Figures 19 through 27 show expanded spectra of day, twilight, and night noise. These spectra are valid from $100 \mathrm{~Hz}$ to $3 \mathrm{kHz}$.

Data in figures 8 through 27 is absolute and has an uncertainty of $\pm 1 \mathrm{~dB}[1]$. This uncertainty only applies over the following frequency ranges: figures 8 and $9,300 \mathrm{~Hz}$ to $2600 \mathrm{~Hz}$; figures 10 through $18,560 \mathrm{~Hz}$ to $10 \mathrm{kHz}$; figures 19 through $27,100 \mathrm{~Hz}$ to $3 \mathrm{kHz}$. See section 9.0, Appendix, for the code key to use in determining the meaning of the numbers in the header block at the top of each spectrum. The resolution bandwidth is given on the ordinate of the plots. 


\subsection{Conclusions}

The surface noise at a remote site, away from powerlines, will not be free of powerline harmonics; their amplitudes will be reduced.

The earth-ionosphere may provide a waveguide to propagate distant noise, particularly above $3500 \mathrm{~Hz}$ during the day and above $1700 \mathrm{~Hz}$ at night. These frequencies are valid only during the period covered by these measurements, as ionospheric phenomena are quite time, geographically, and seasonally dependent.

\subsection{Recommendations}

These limited results indicate that emergency locator beacon frequencies should be selected below $1700 \mathrm{~Hz}$ and between harmonics of the $60 \mathrm{~Hz}$ powerline frequency.

Additional measurements should be made over a diurnal cycle and during each of the four seasons. Higher gain baluns and/or amplifiers should be used to lower system noise.

\subsection{Acknowledgments}

Ed Niesen assisted with the field work, Winston Scott assisted with the data processing, and Sharon Foote and Janet Becker performed typing services.

David Sterns at the University of Colorado assisted with digitizing data.

Carl Fisher and Ruben Mayes of Westinghouse Georesearch Laboratory made arrangements with Mr. Watson of Geneva Mine of U.S. Steel Co. Fisher and Mayes assisted in specifying locations, frequencies, and overburden with respect to emergency locator beacons.

Frank Cowley and Lorne Matheson of the National Oceanic and Atmospheric Administration assisted with computer software and data processing. 


\subsection{References}

[1] Bensema, W.D., M. Kanda, and J.W. Adams, "Electromagnetic Noise in Robena No. 4 Mine," NBS Technical Note 654 , Apri1 1974 .

[2] Ramo and Whinnery, "Fields and Waves in Modern Radio" (John Wiley \& Sons, Inc., New York, New York, Second Edition, p. 328, p. 335, etc., 1959).

[3] Terman, "Electronic and Radio Engineering" (McGrawHi11 Book Co., Inc., New York, New York, Fourth Edition, p. $825,826,1955)$. 


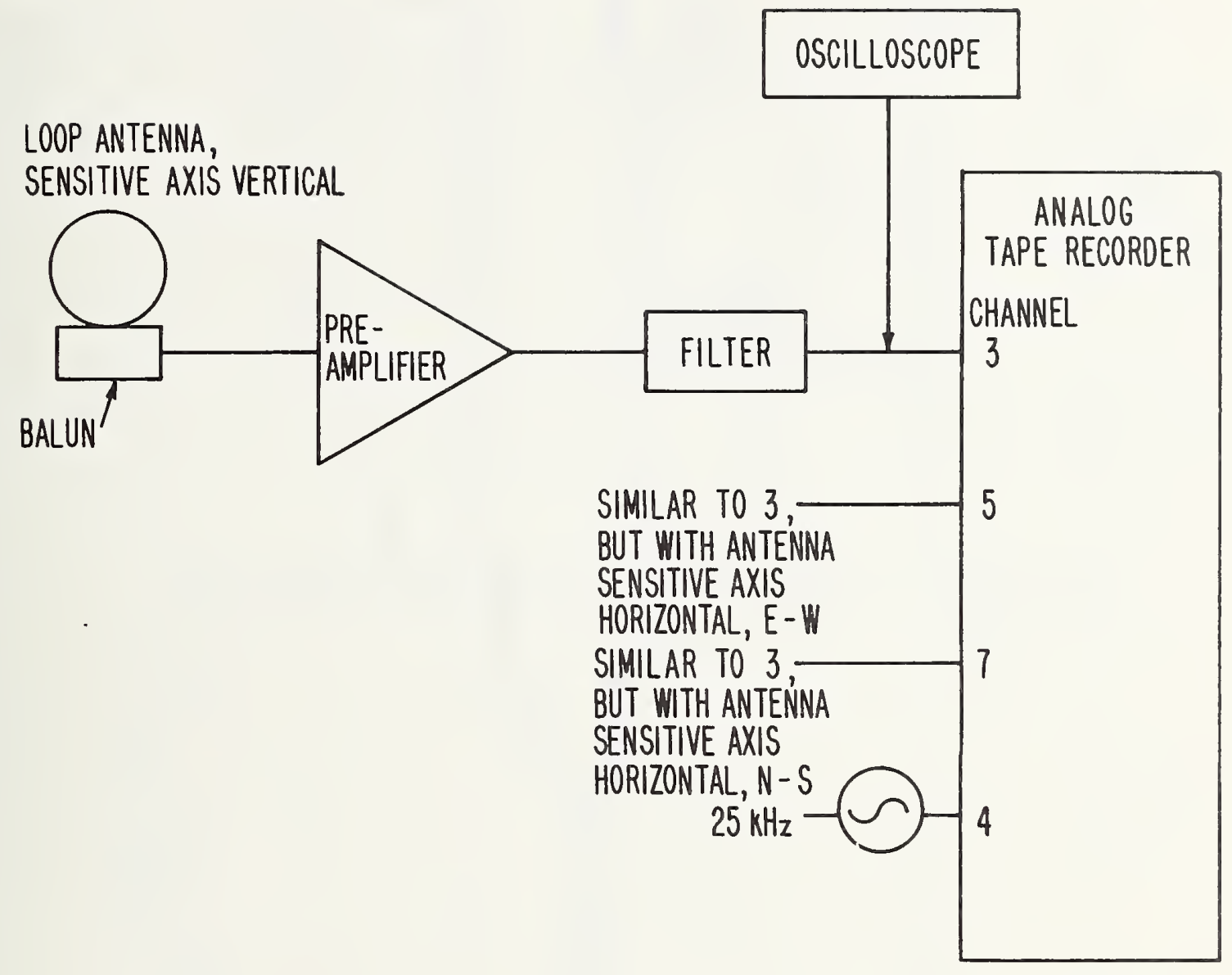

Figure 1. Field Recording System 


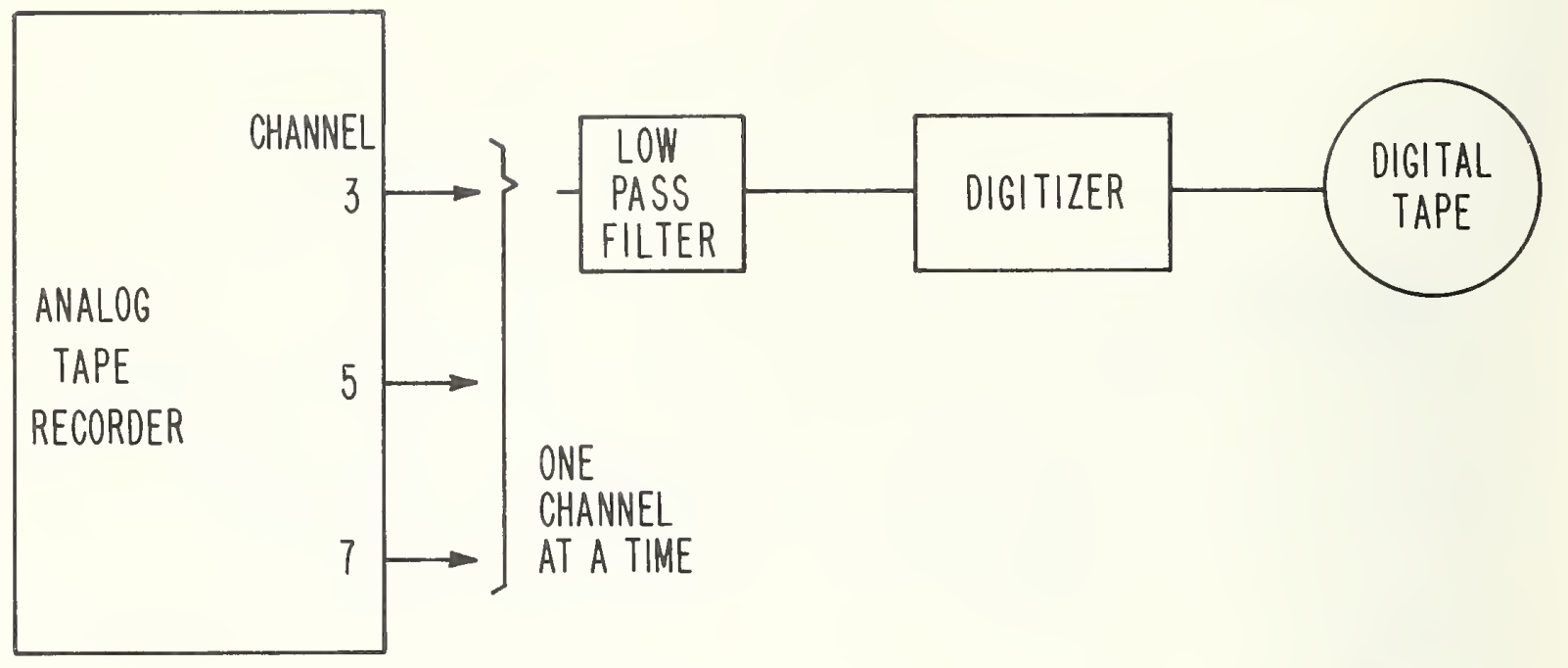

Figure 2a. Digitizing part of data processing system

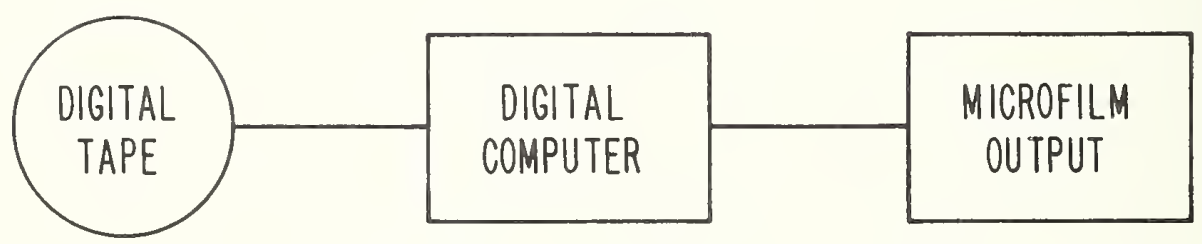

Figure 2b. Fast-Fourier transform part of data processing system 


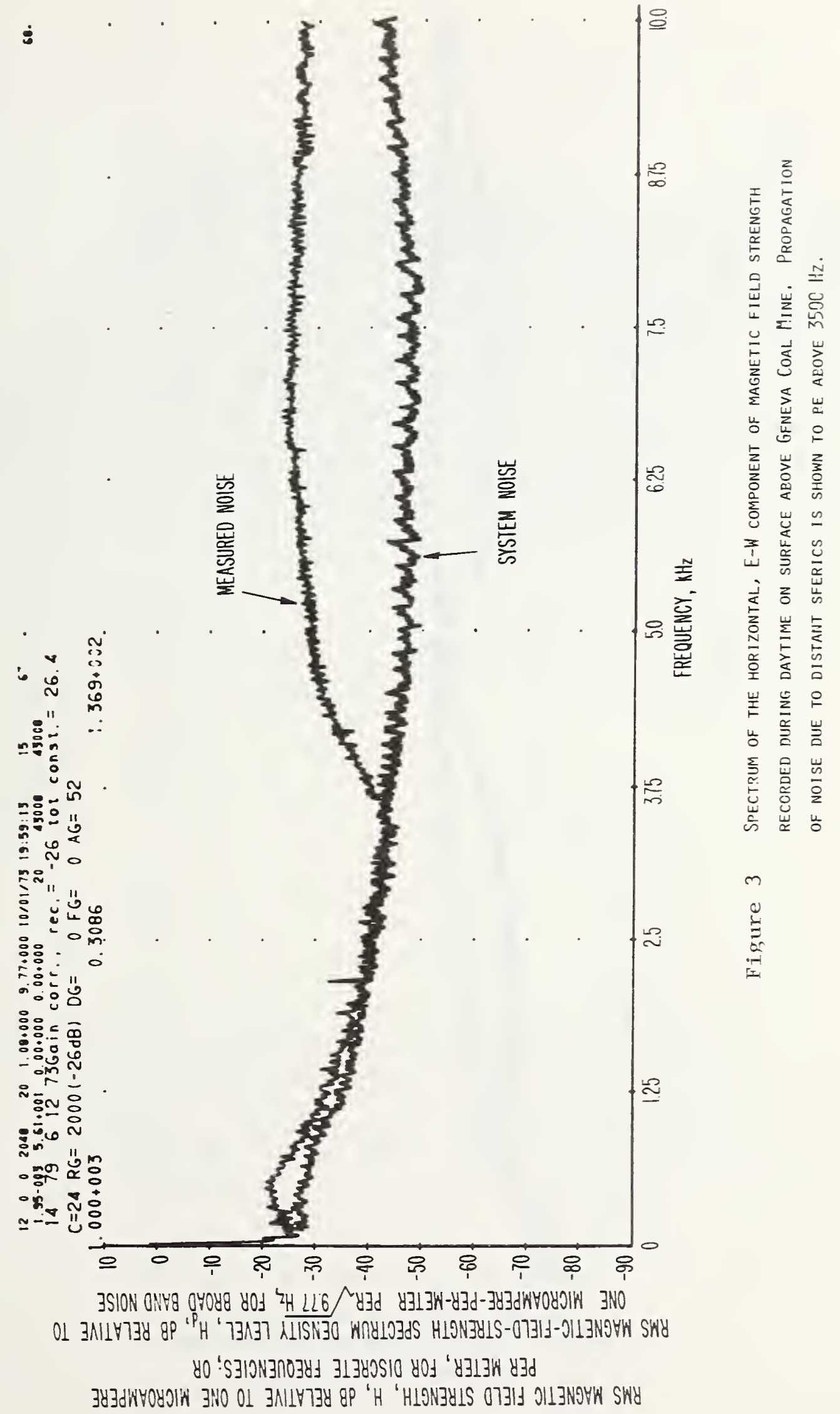




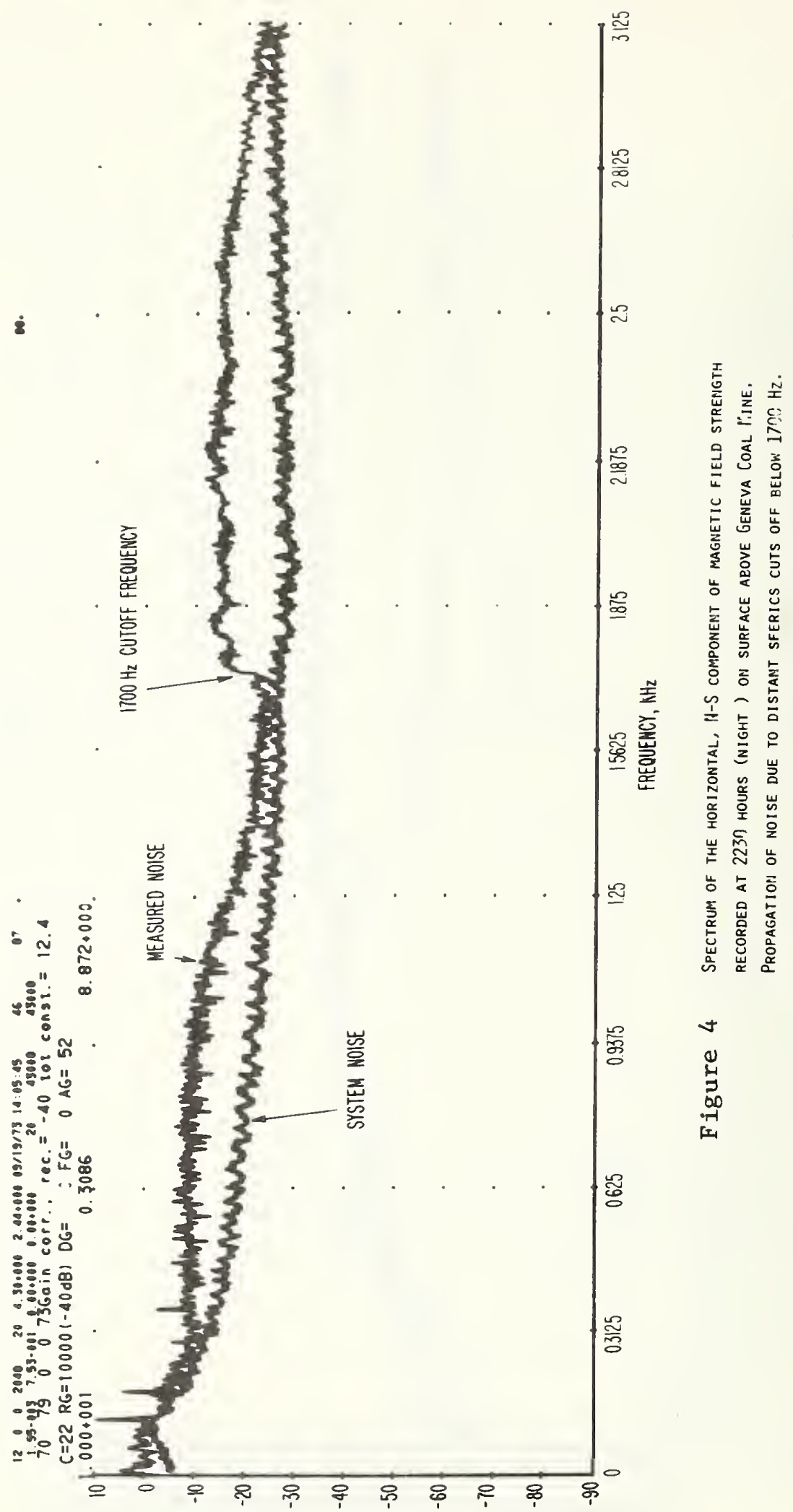

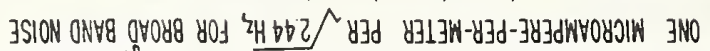

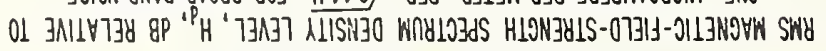

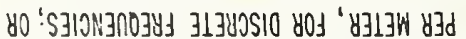

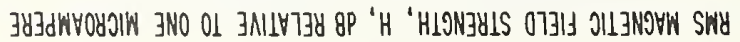




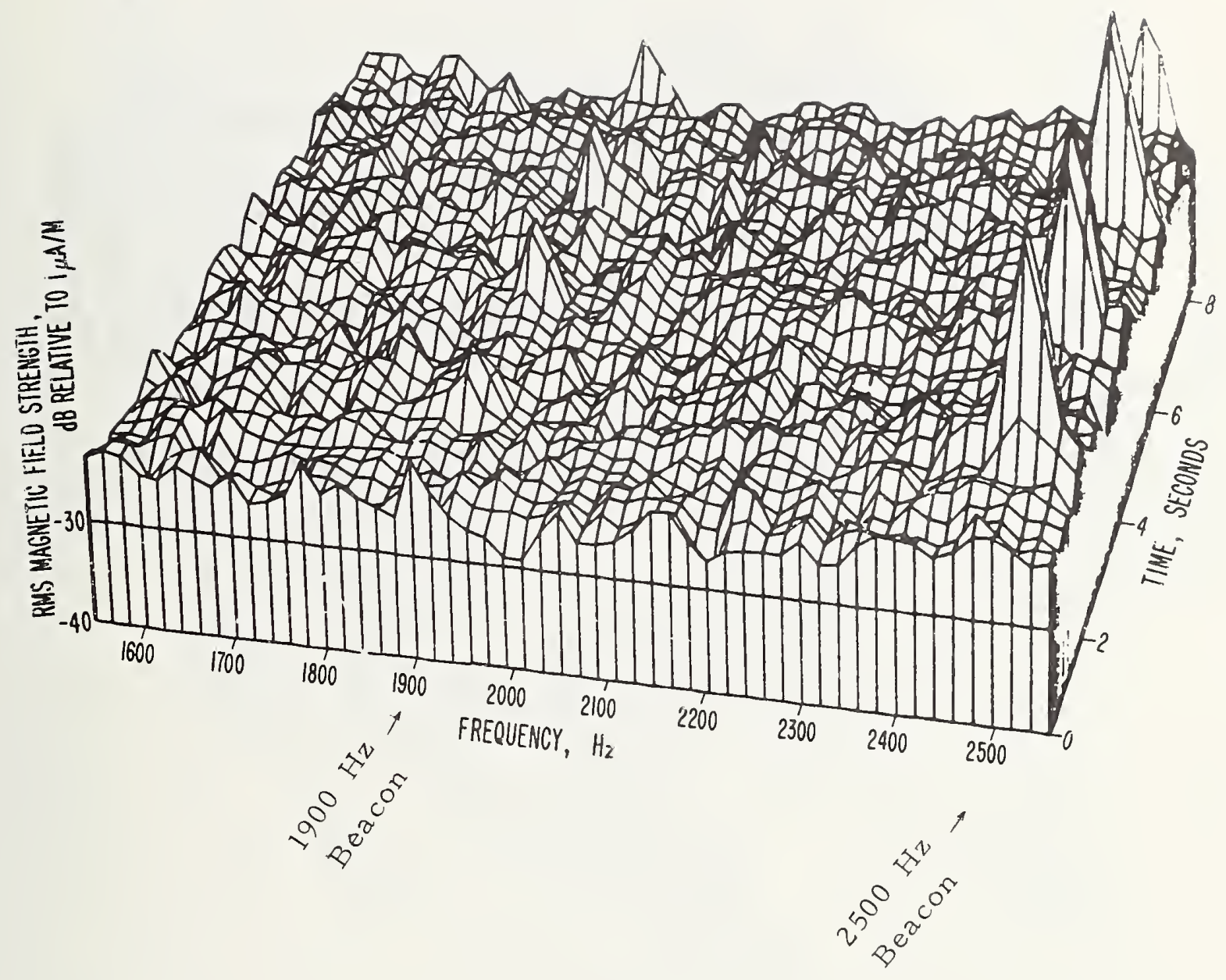

Figure 5 Spectrum of magnetic field strength vs. time. Antenna placed on surface of ground above Geneya Coal Mine, daytime. "Lost-Miner Beacon" pulses showing at $2500 \mathrm{~Hz}$ are from a transmitter beacon straight down 351 meters (1150 feet). Pulses at $1900 \mathrm{~Hz}$ are from a transmitter 0.8 kilometers ( $1 / 2$ mile) away under 463 meters (1520 feet) of overburden. 


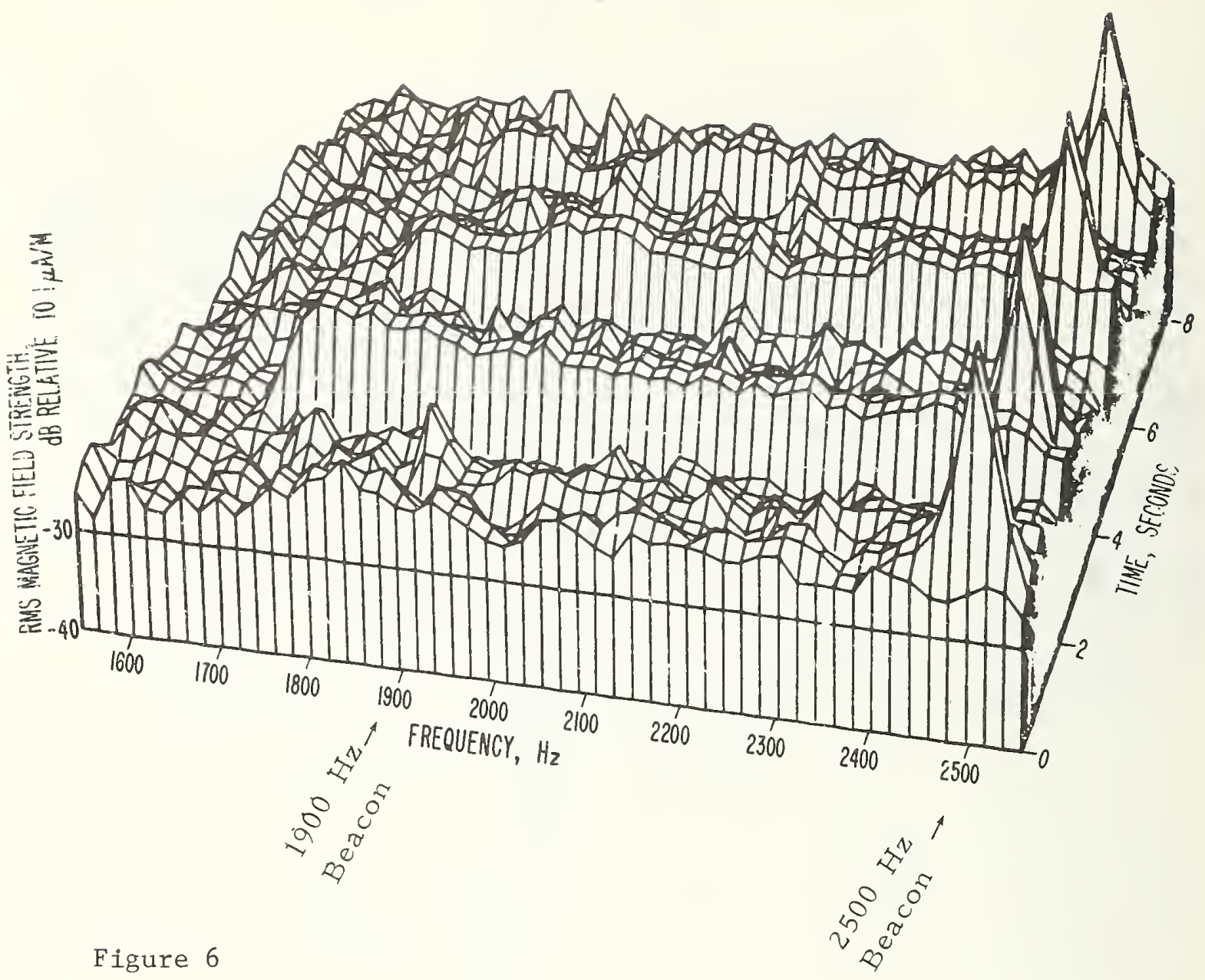

Soectrum of magnetic field strength vs. time. Antenna placed on surface of ground above Geneva Coal Mine, nighttime. "Lost-Miner Beacon" pulses at $2500 \mathrm{~Hz}$ can still be seen but those at $1900 \mathrm{~Hz}$ are cartially obscured by the atmospheric pulses (lightning static) prnnagating in from over the horizon. This plot shows that by placing transmitter frequency below $1600 \mathrm{~Hz}$, atmospheric interference can be reauced at least $10 \mathrm{~dB}$, a factor of 10 th 1 reduction in nower. 


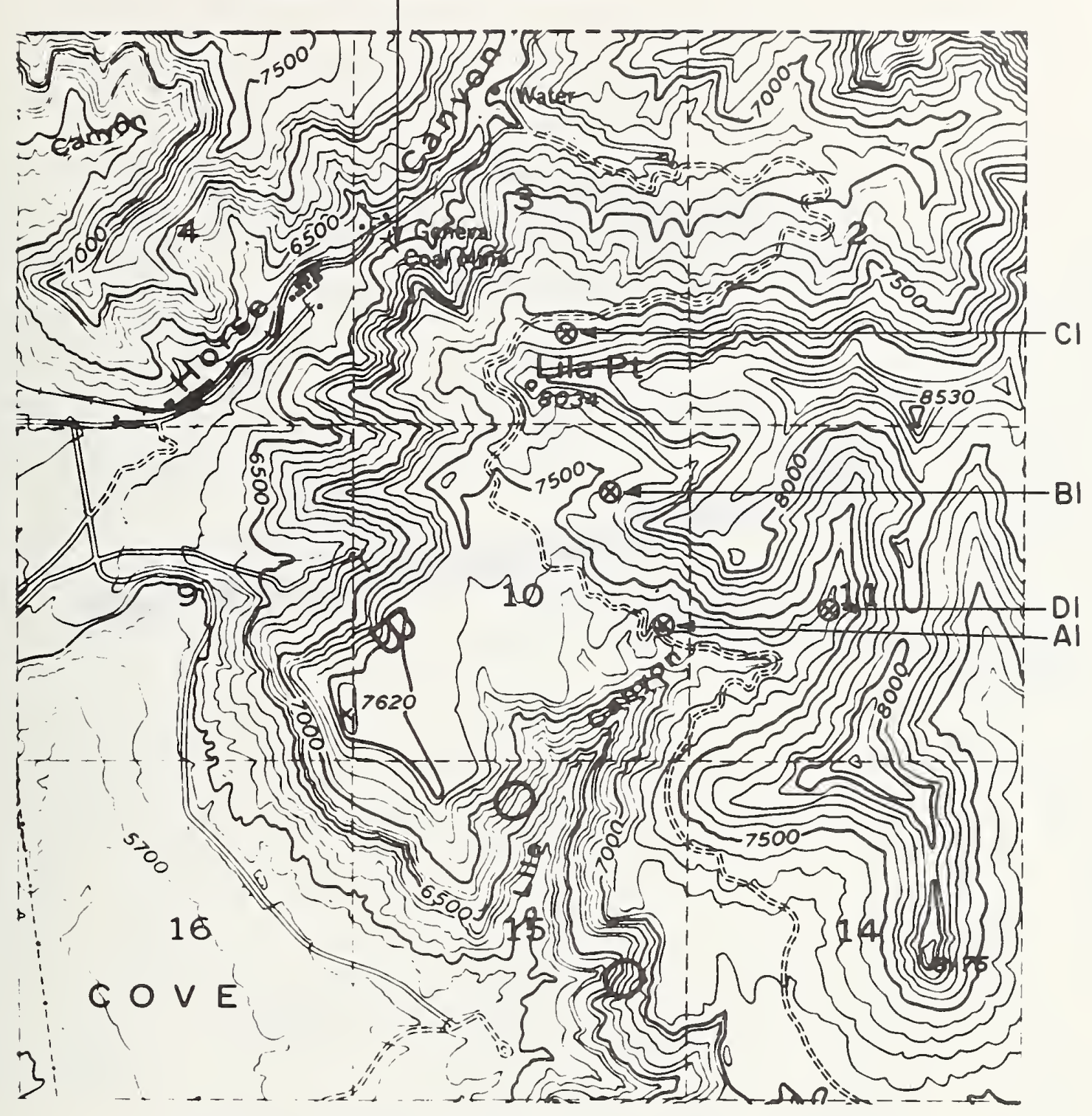

Figure 7 Map of surface over Geneva Coal Mine.

$\begin{array}{ccc}\begin{array}{c}\text { Location } \\ \text { Code }\end{array} & \text { Overburden } & \text { Beacon Frequency } \\ (\mathrm{Hz})\end{array}$

\begin{tabular}{c|c|c}
\hline A1 & 350 & 2500.0 \\
\hline B1 & 463 & 1900.0 \\
\hline C1 & 442 & 1700.0 \\
\hline D1 & 503 & 922.5
\end{tabular}




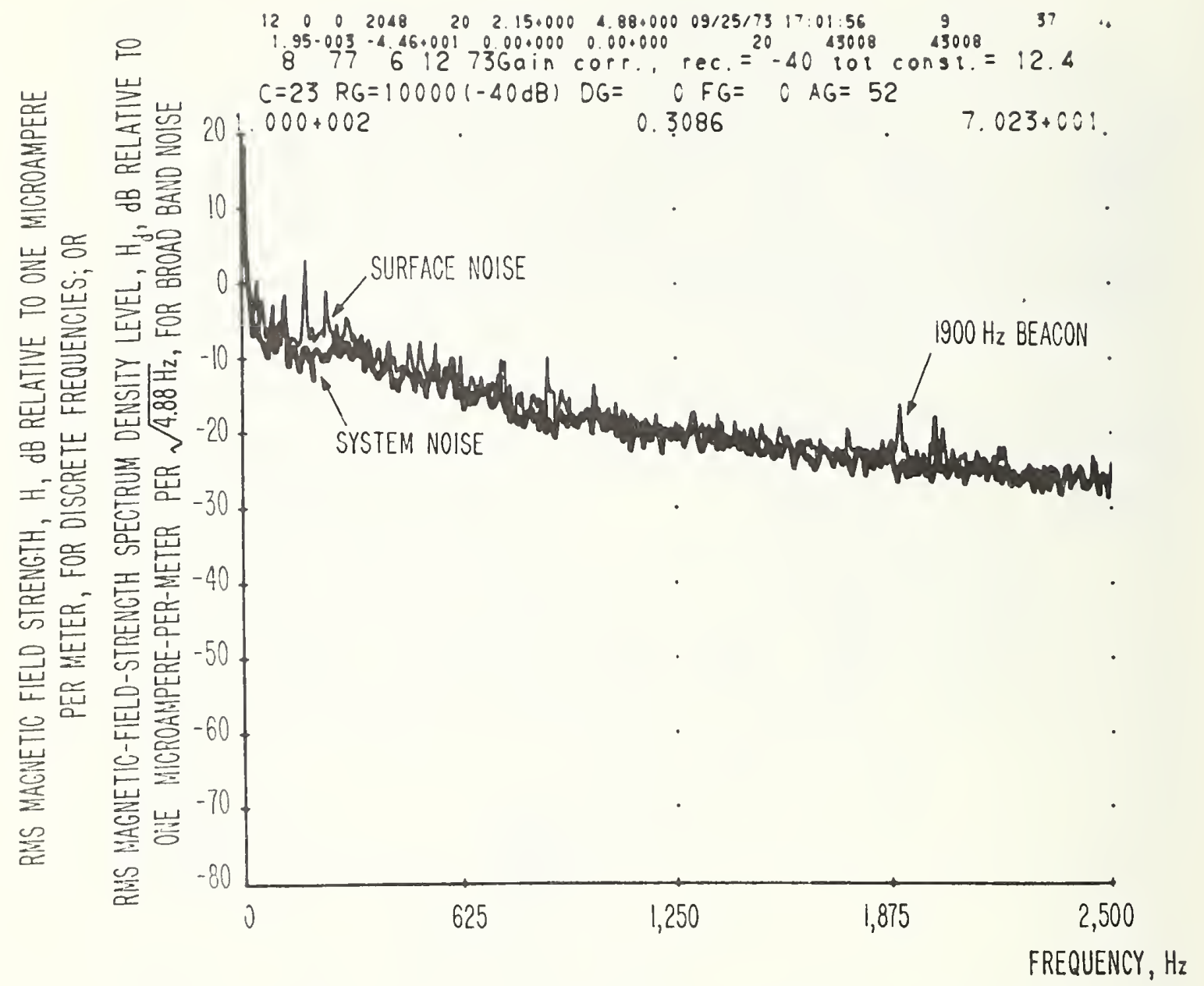

Figure 8 Spectrum of surface EM noise at Lila Flats over Geneva Iline, Location BI on Figure 7. 1900 beacon coming through 463 meters ( $1520 \mathrm{ct}$.) of overburden is barely visible.

Antenna sensitive axis was vertical. Daytime. June 12, 1973. 


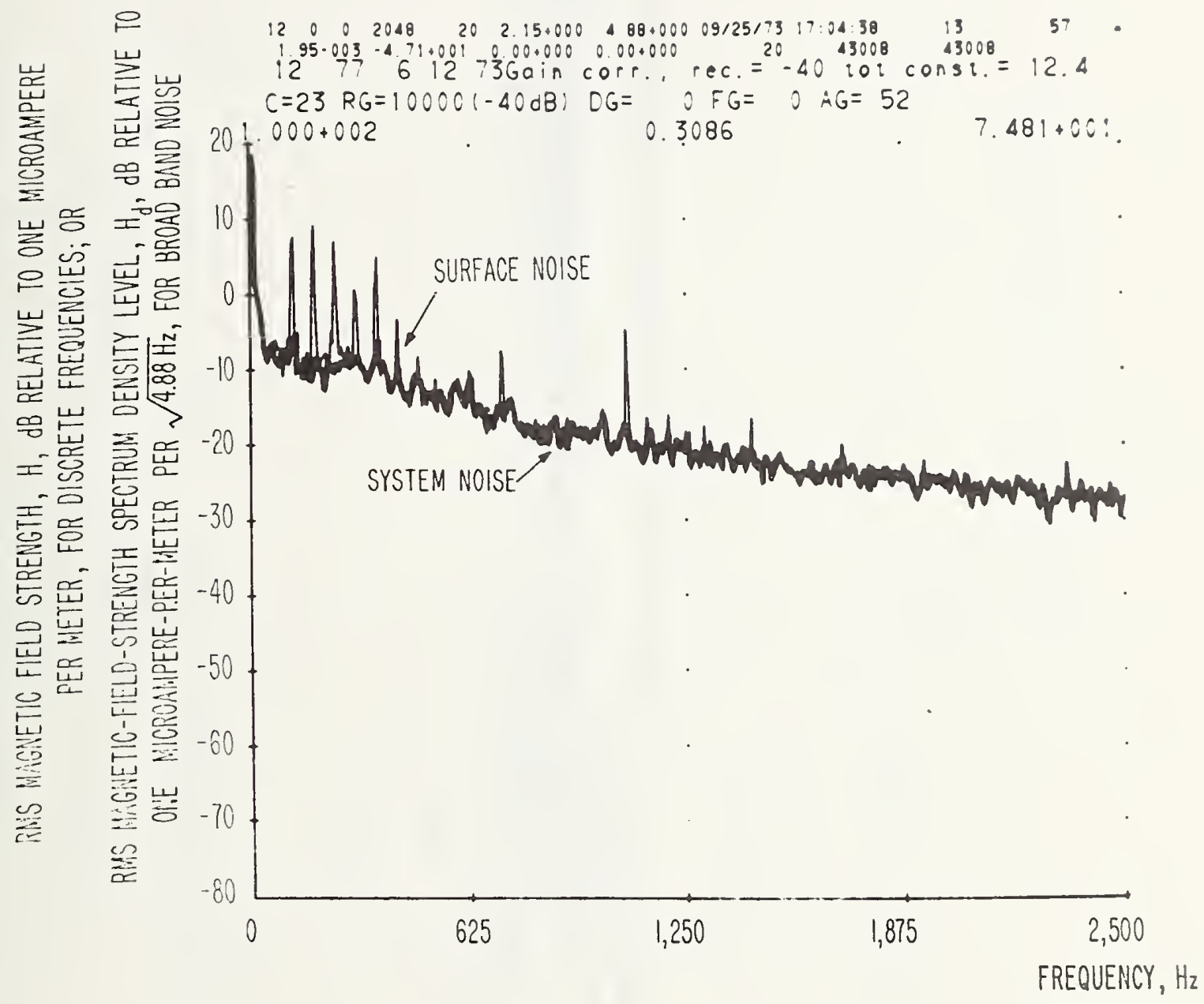

Figure 9 Spectrum of surface EM noise, north side of L1la Point, over reneva Mine, Location C1 on Figure 7. $1700 \mathrm{~Hz}$ beacon

throur: 442 meters ( $1450 \mathrm{ft}$.) of overburden is not visible.

Antenna sensitive axis was vertical. Daytime. June 12, 1973. 


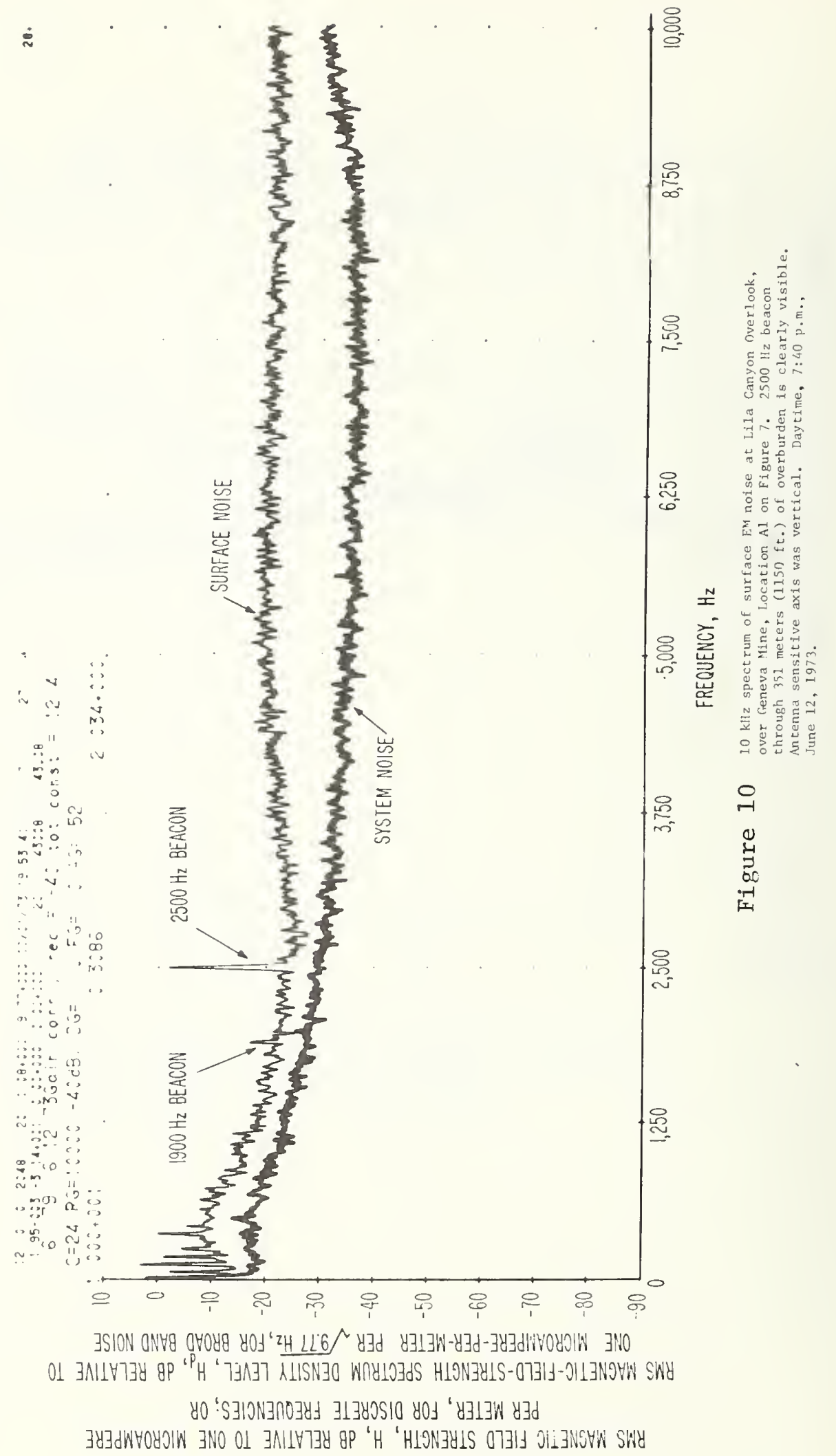




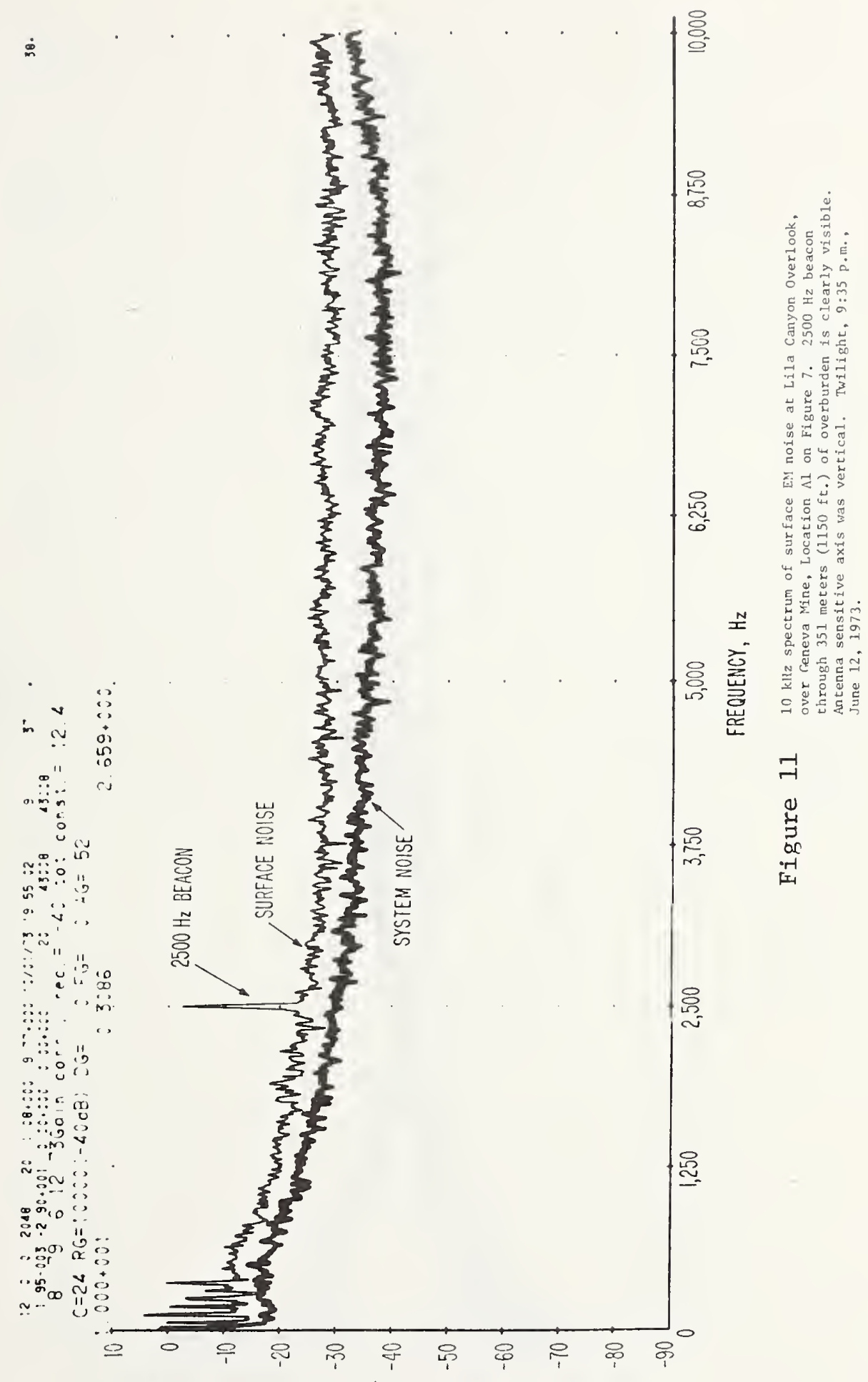

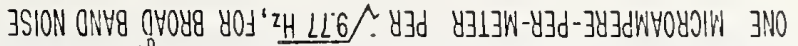

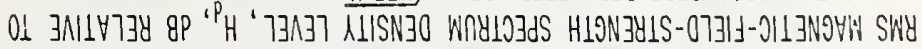

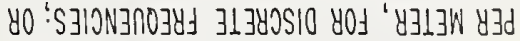

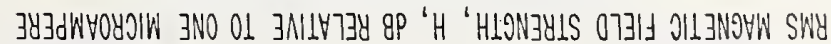




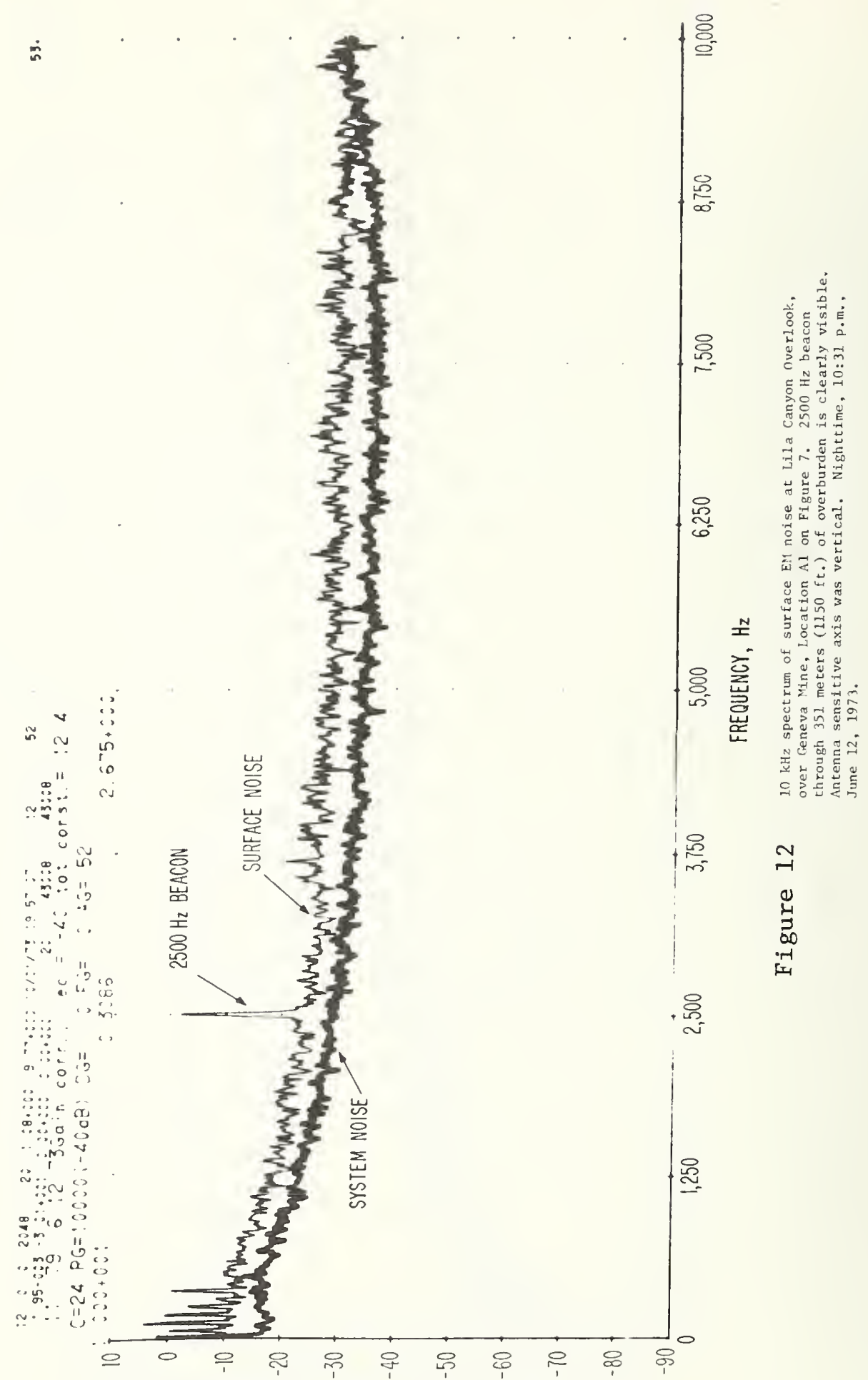

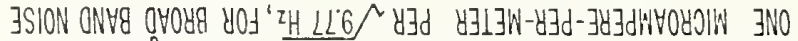

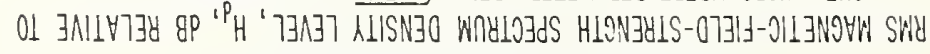

४

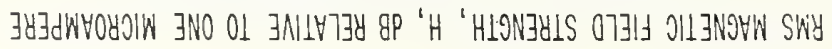




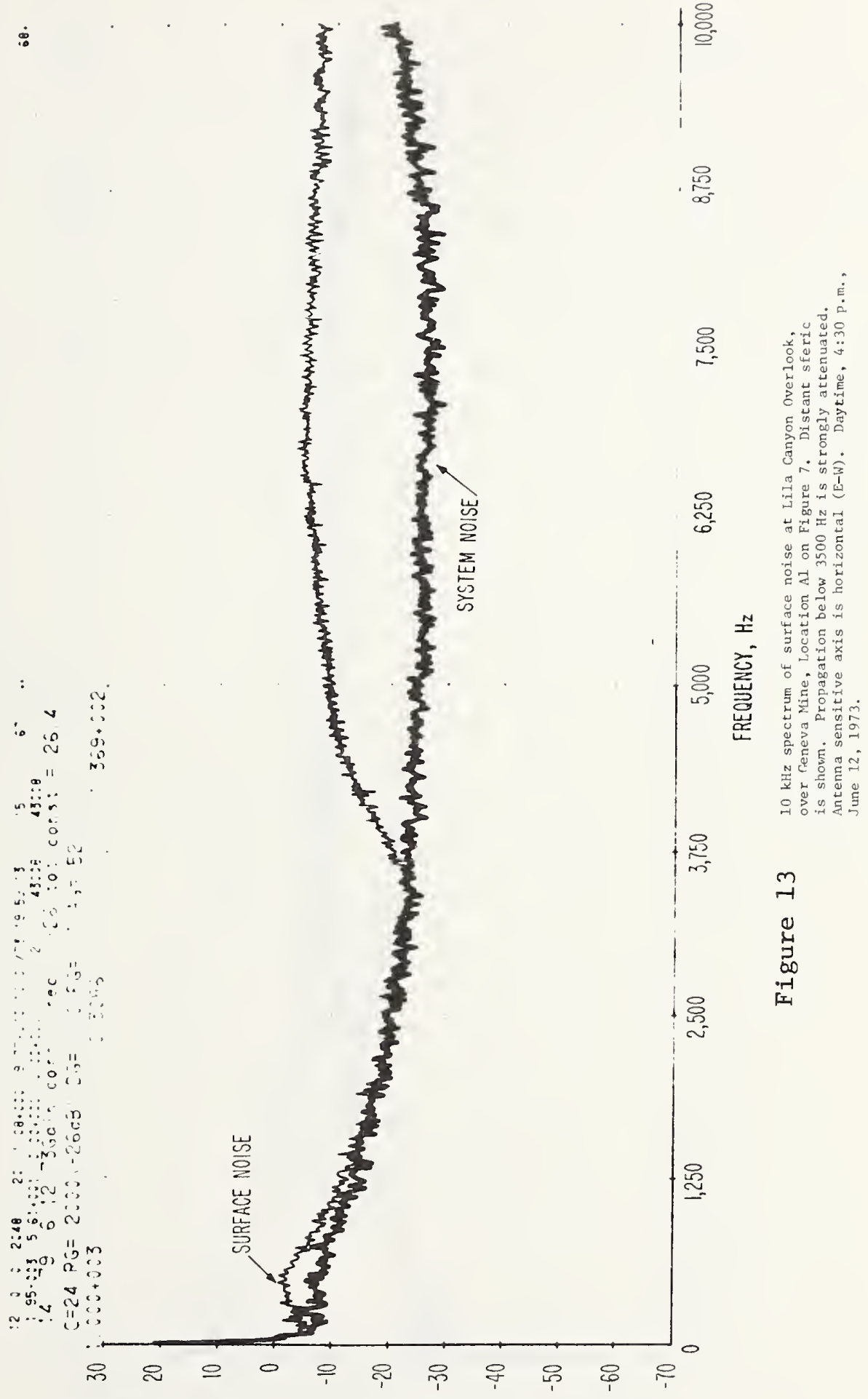

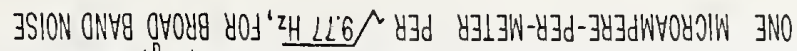

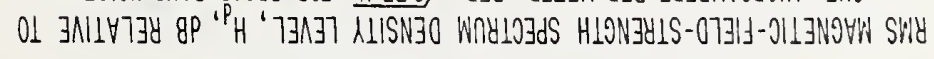

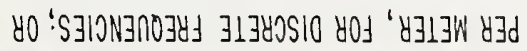

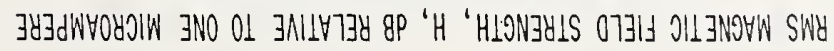




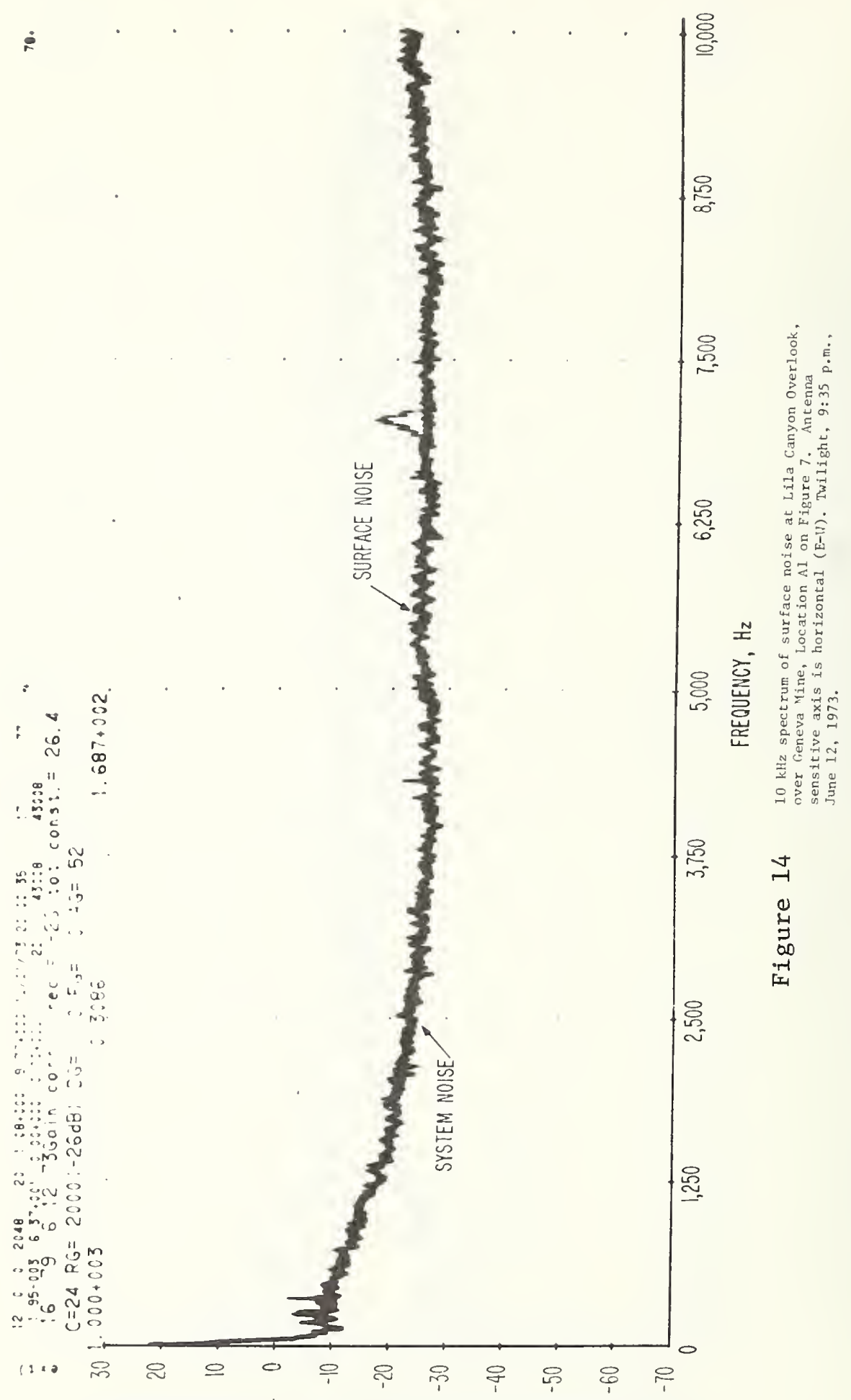

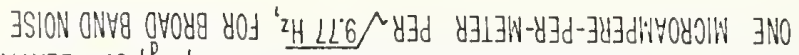

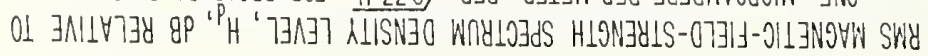
у

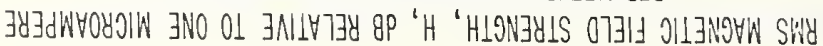




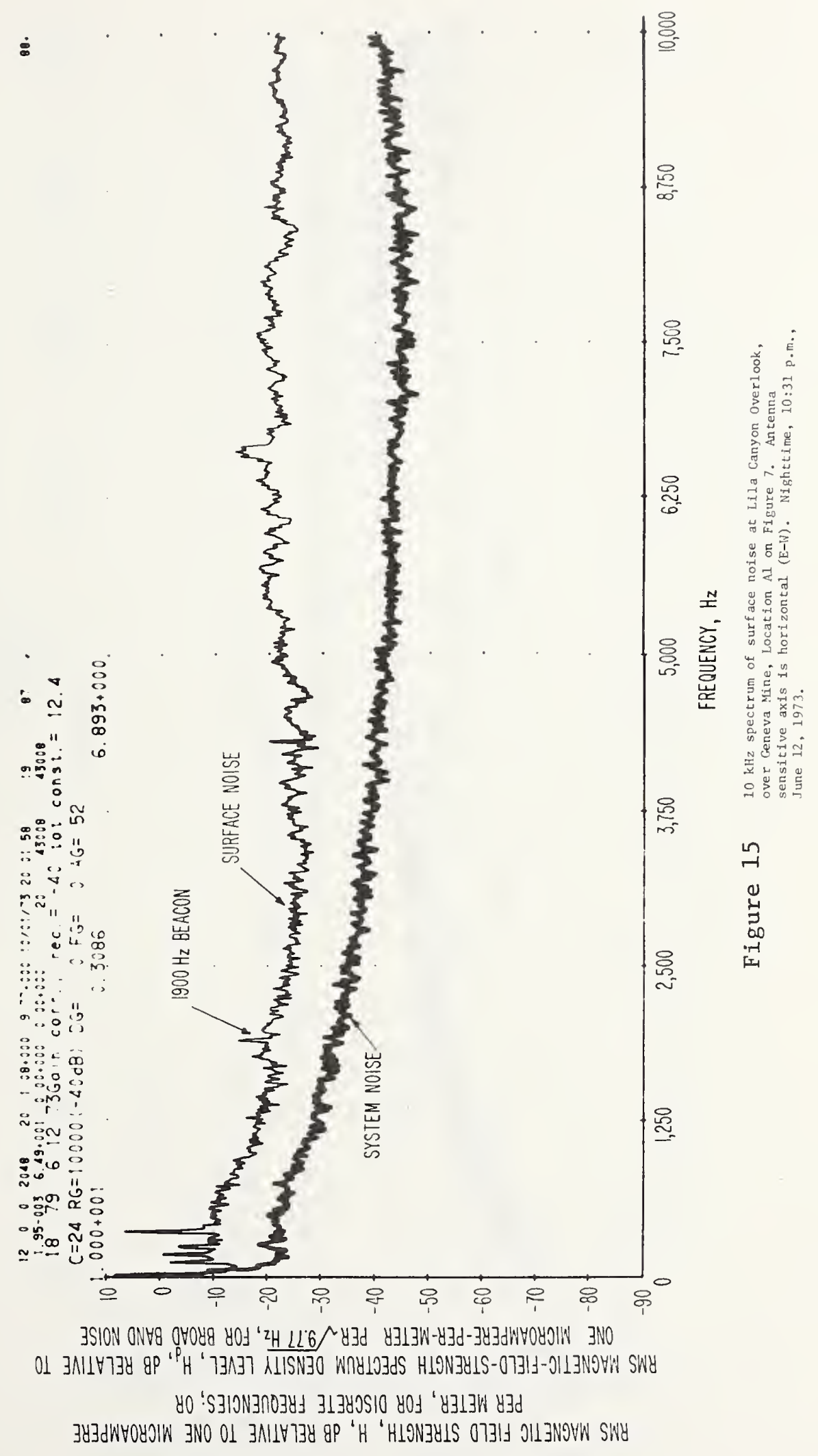




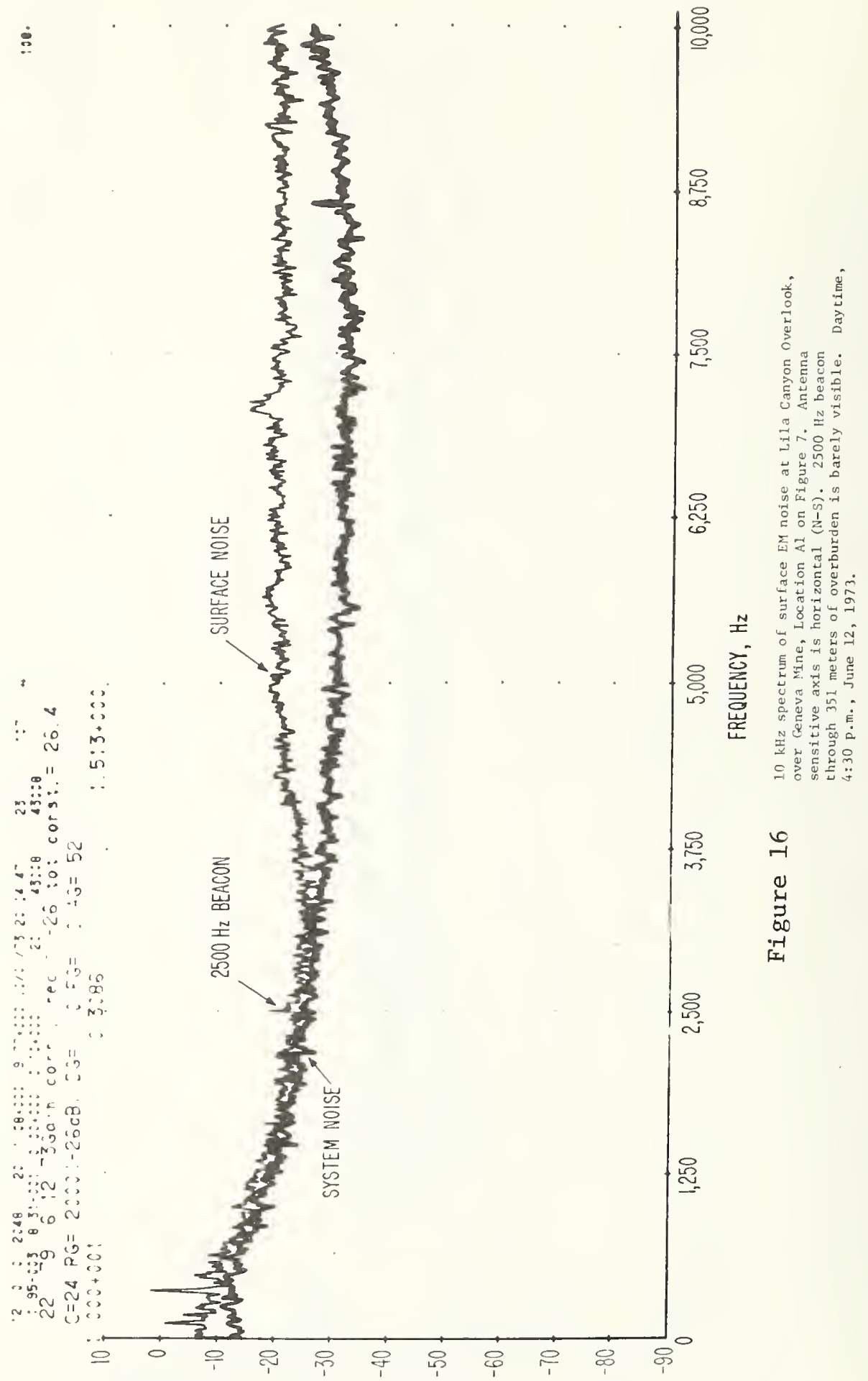

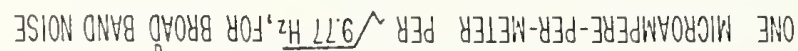

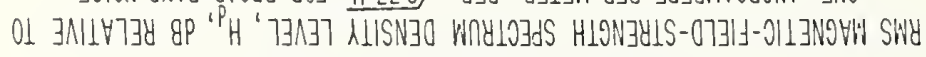

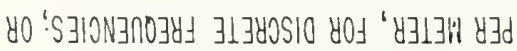

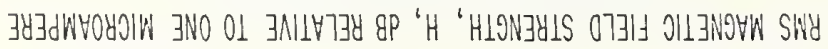




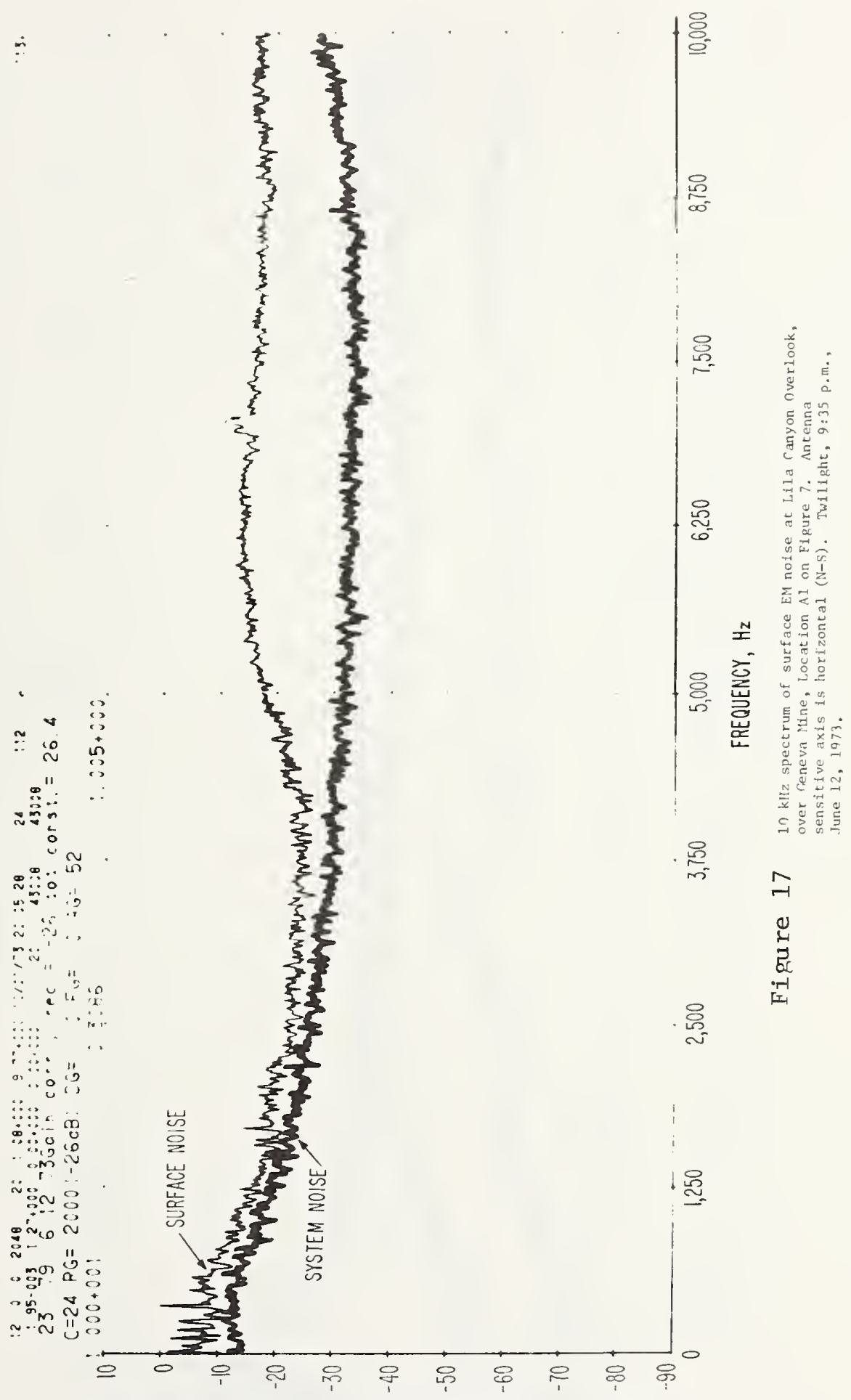

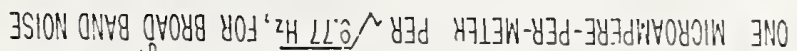

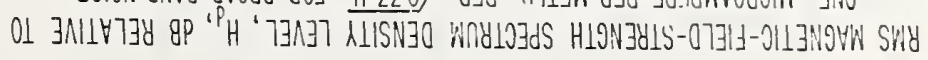

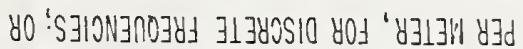

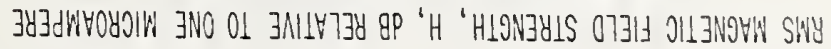




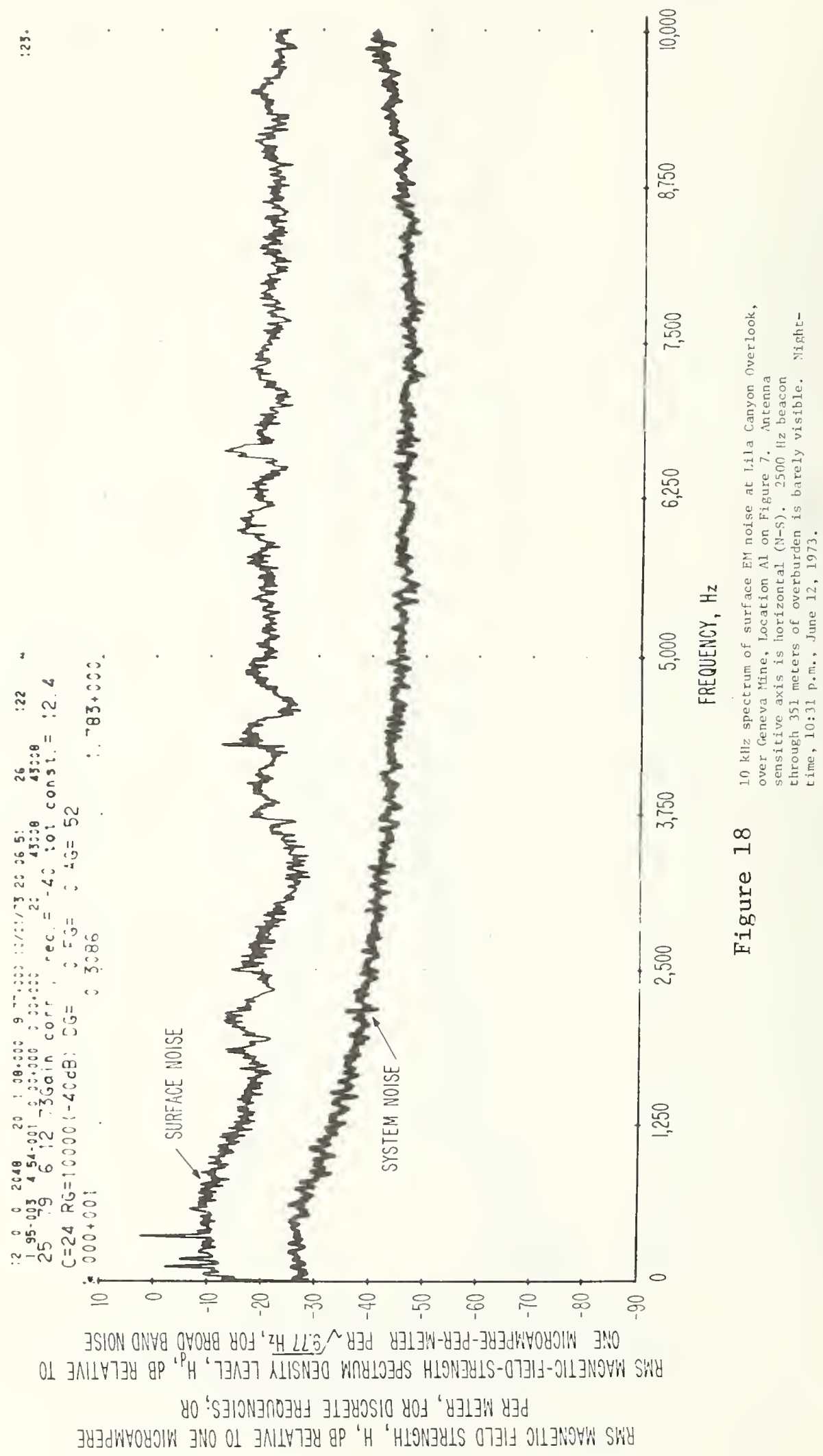




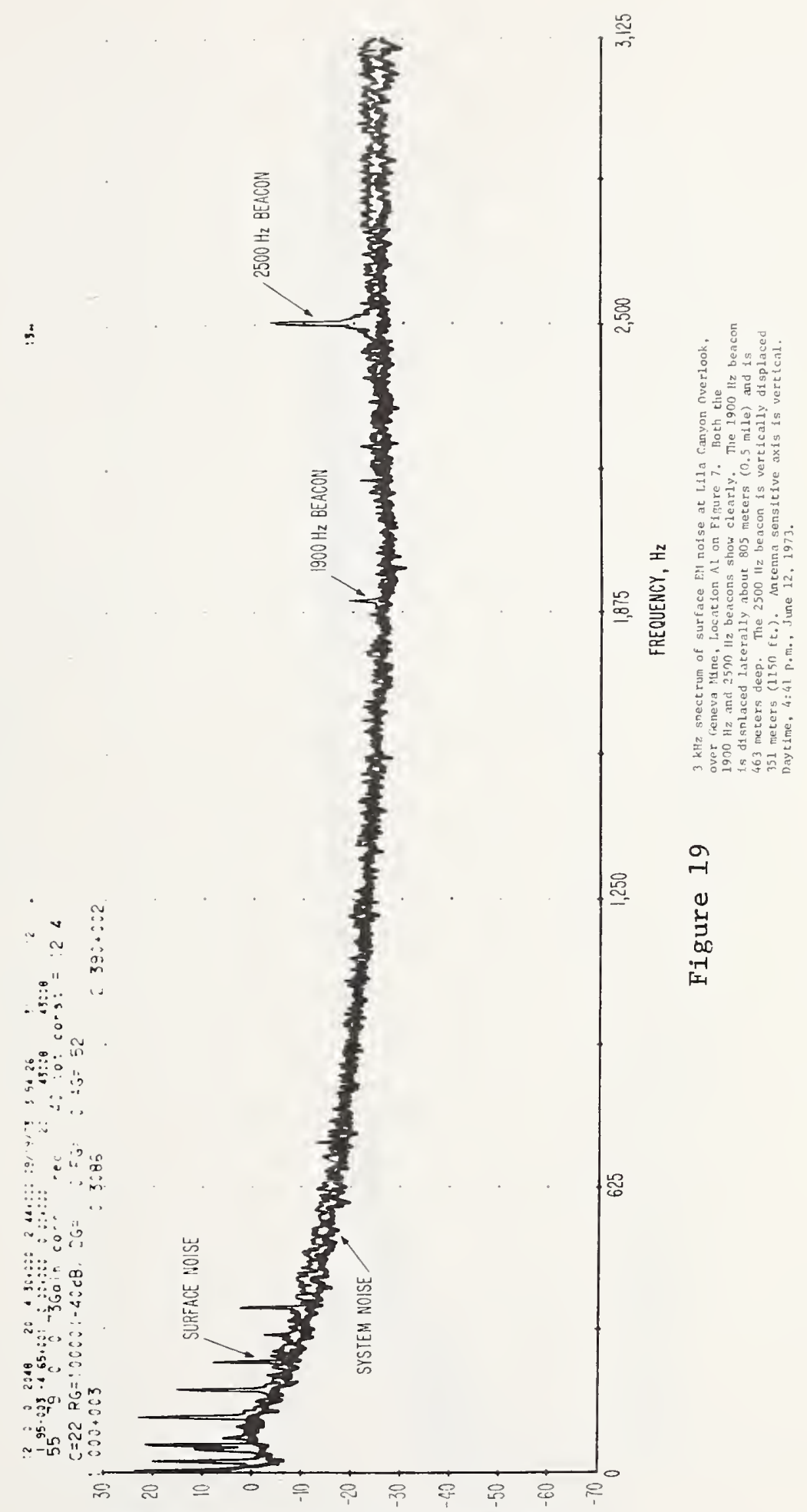

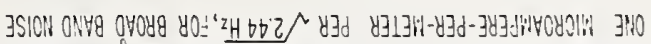

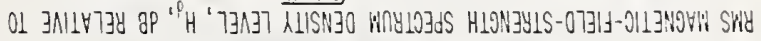

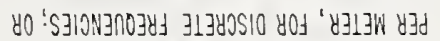

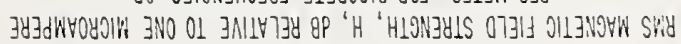




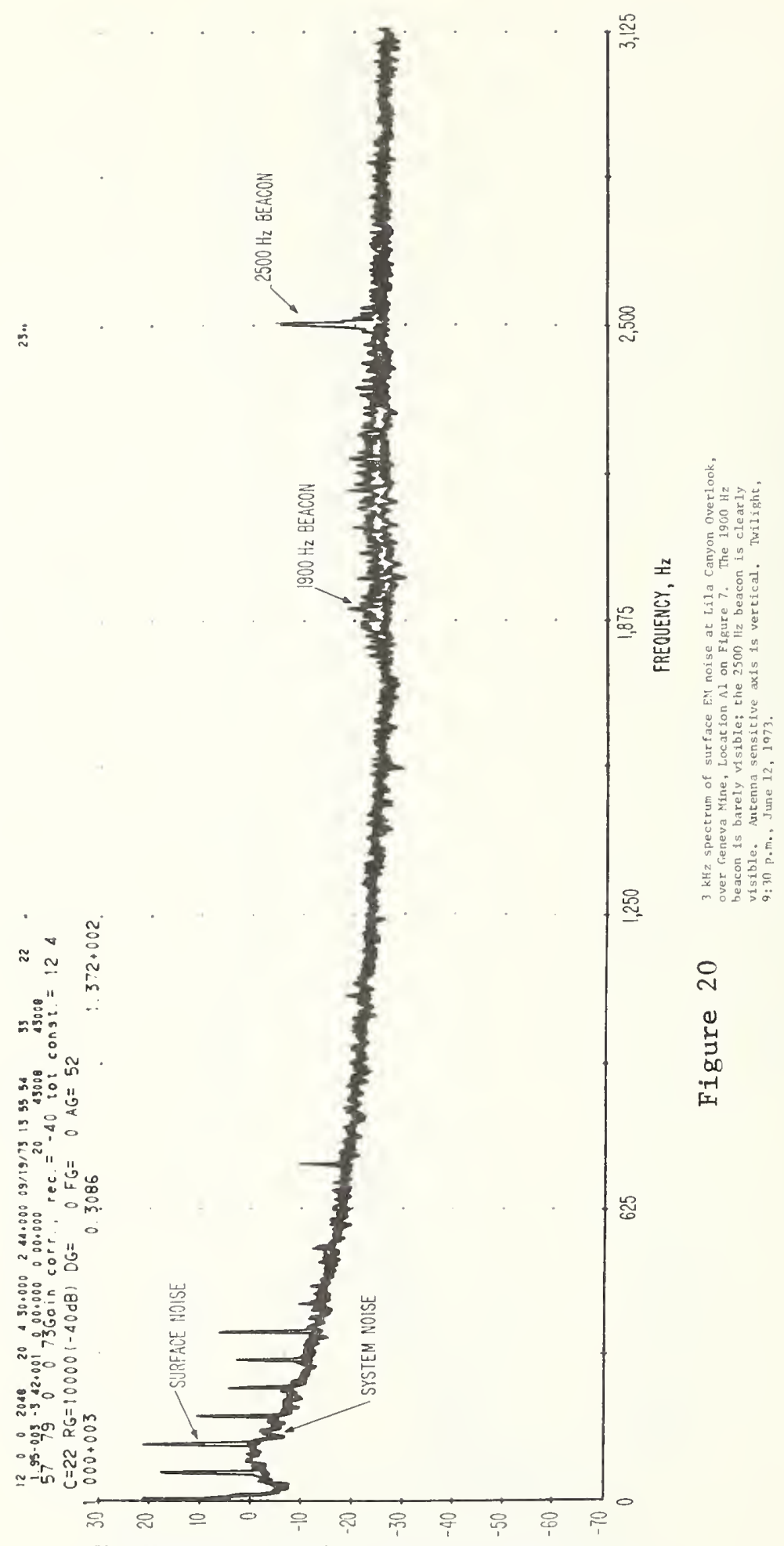

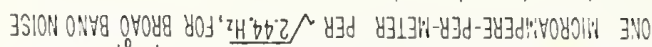

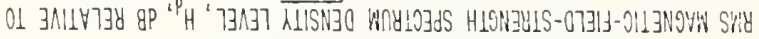

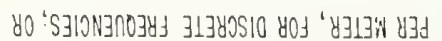

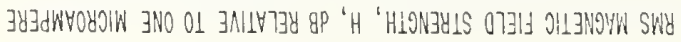




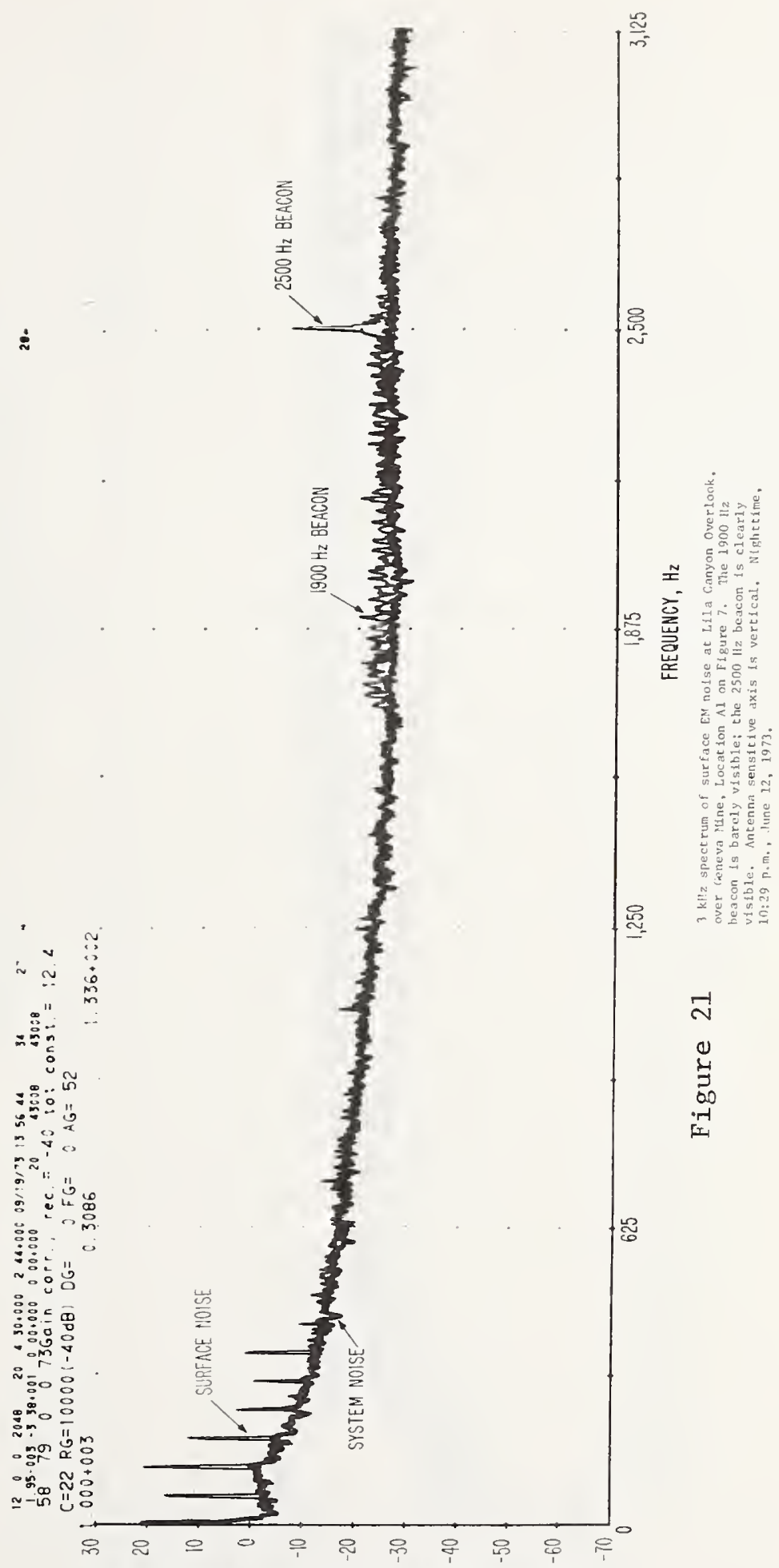

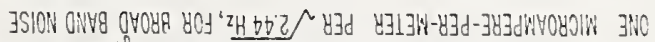

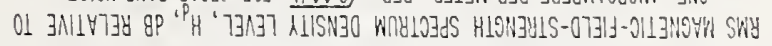

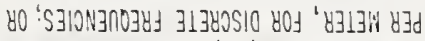

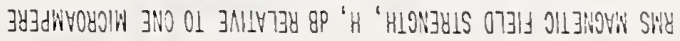




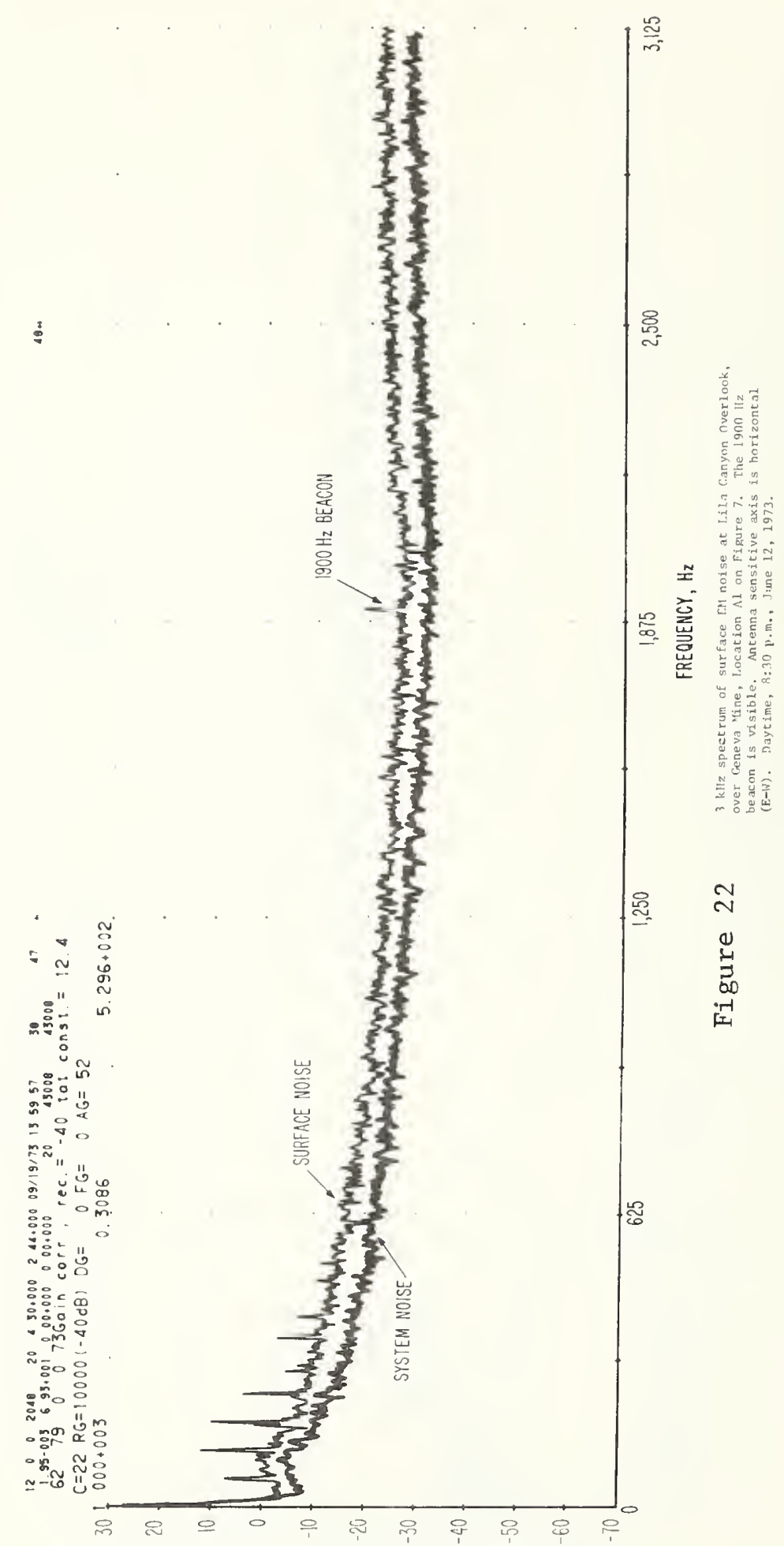

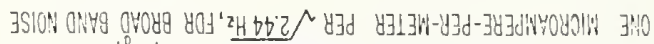

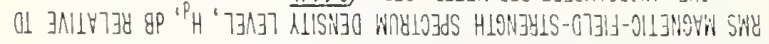

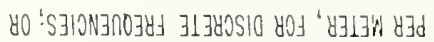

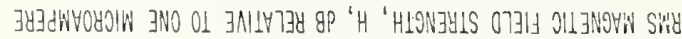




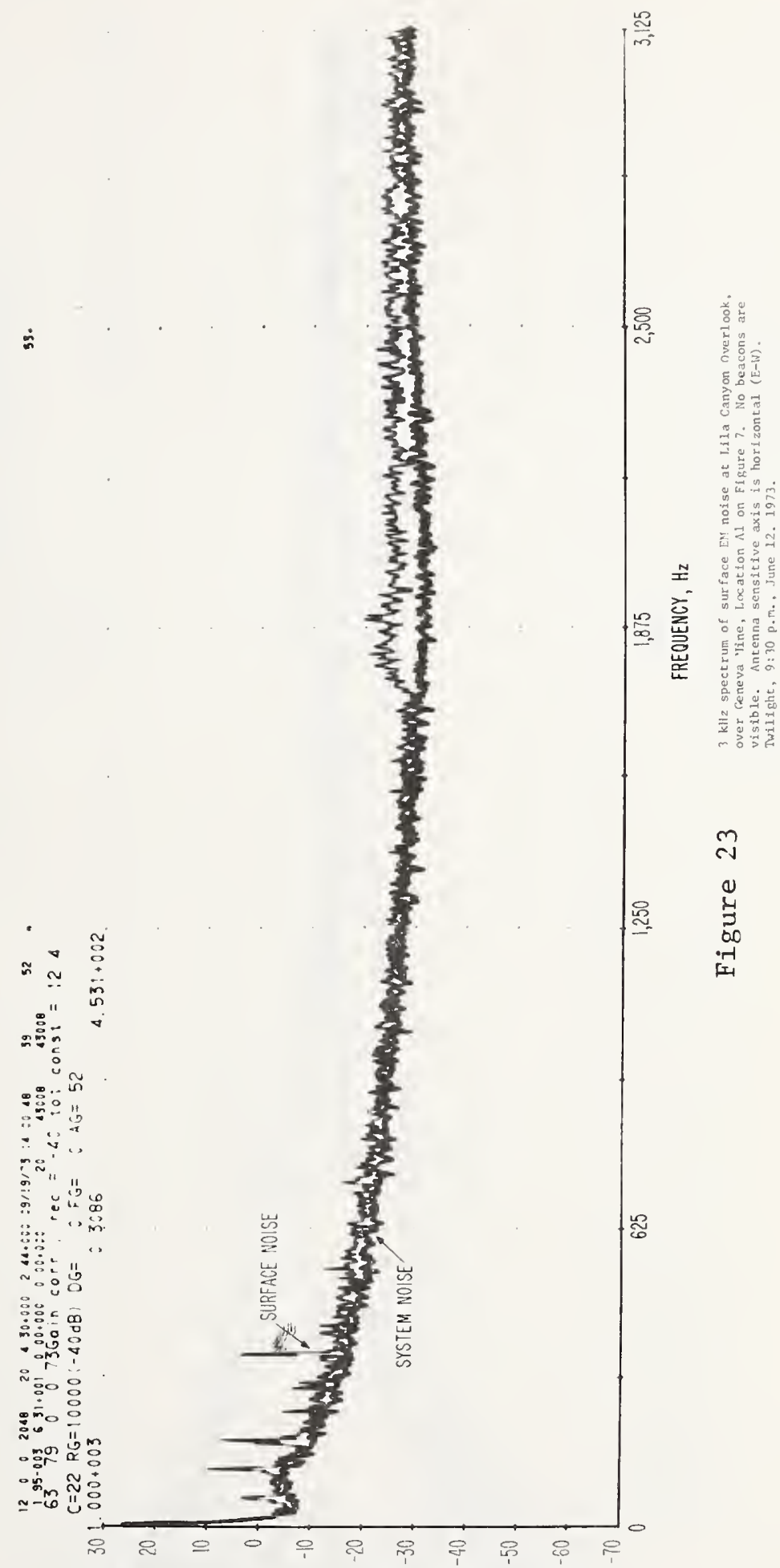

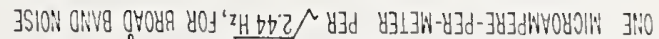

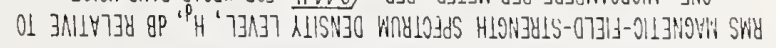

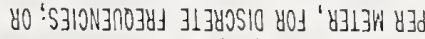

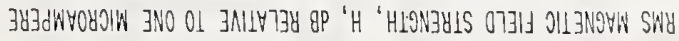




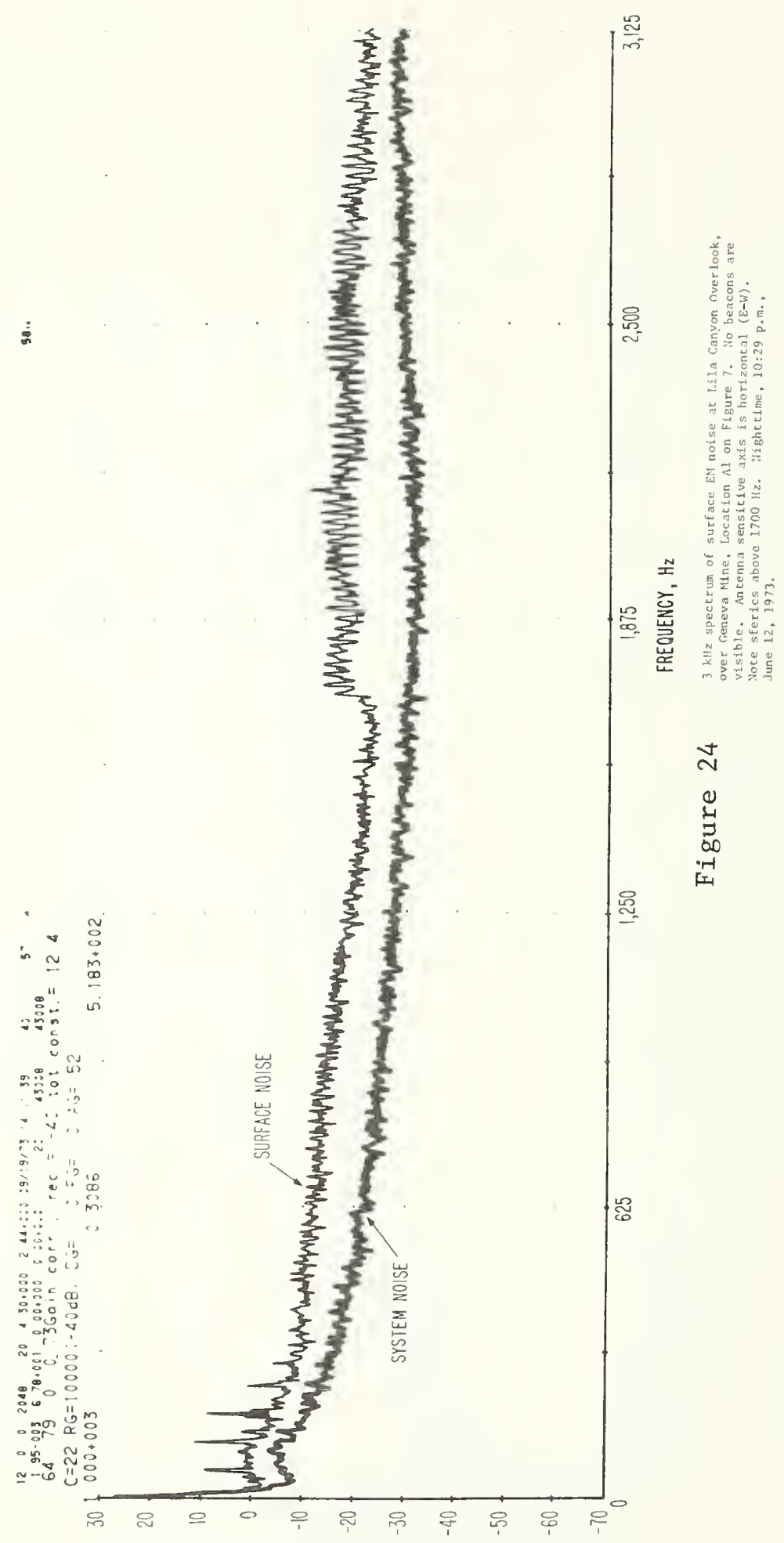

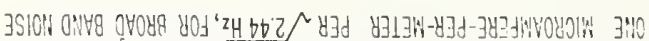

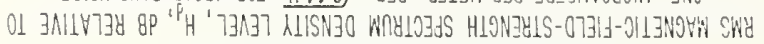

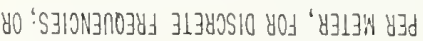

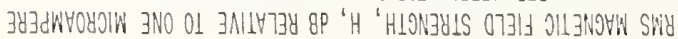




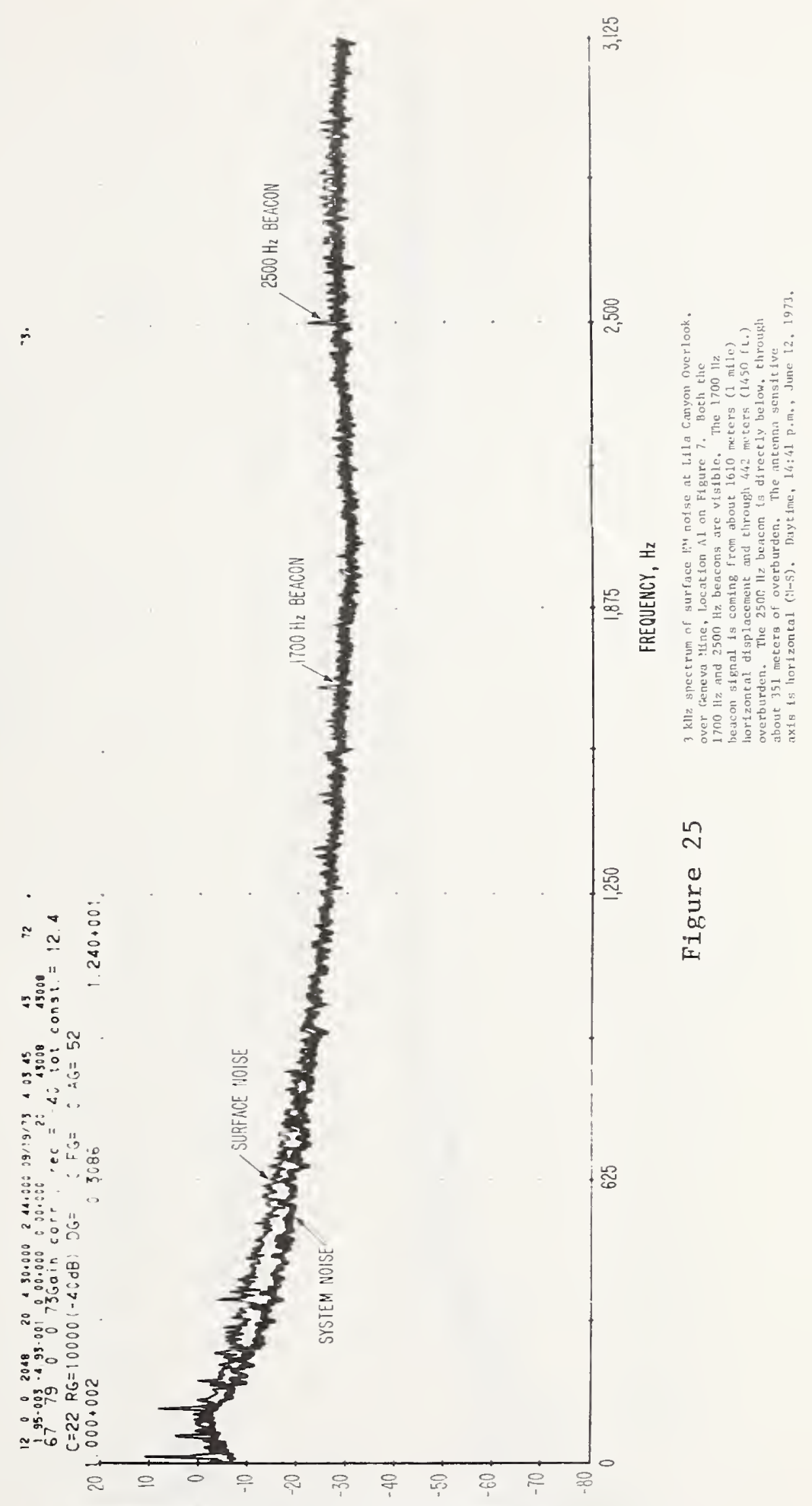

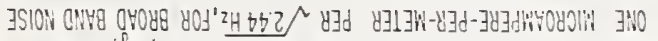

01 JN1L

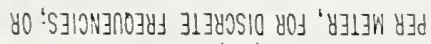

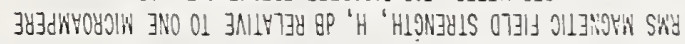




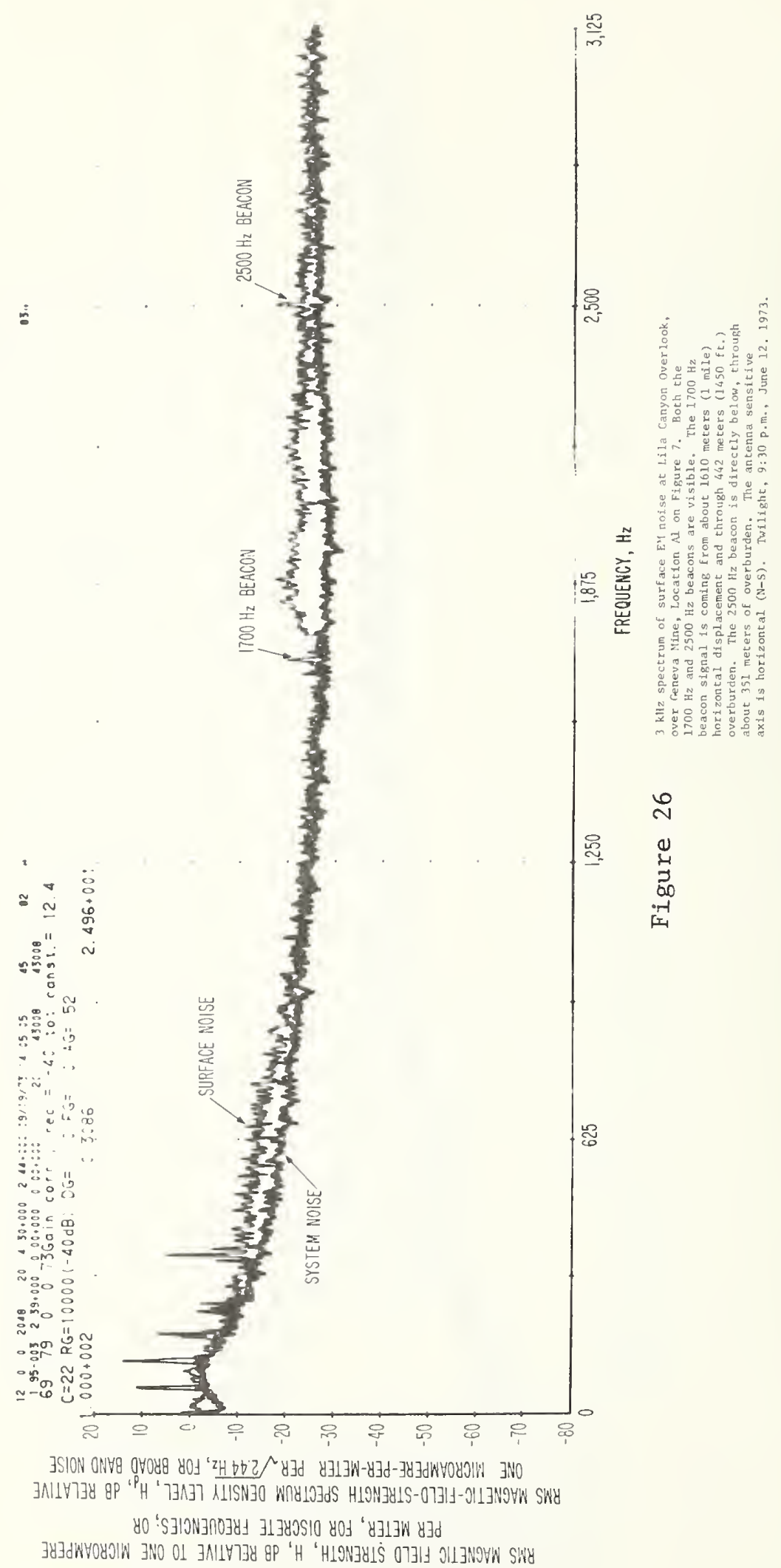




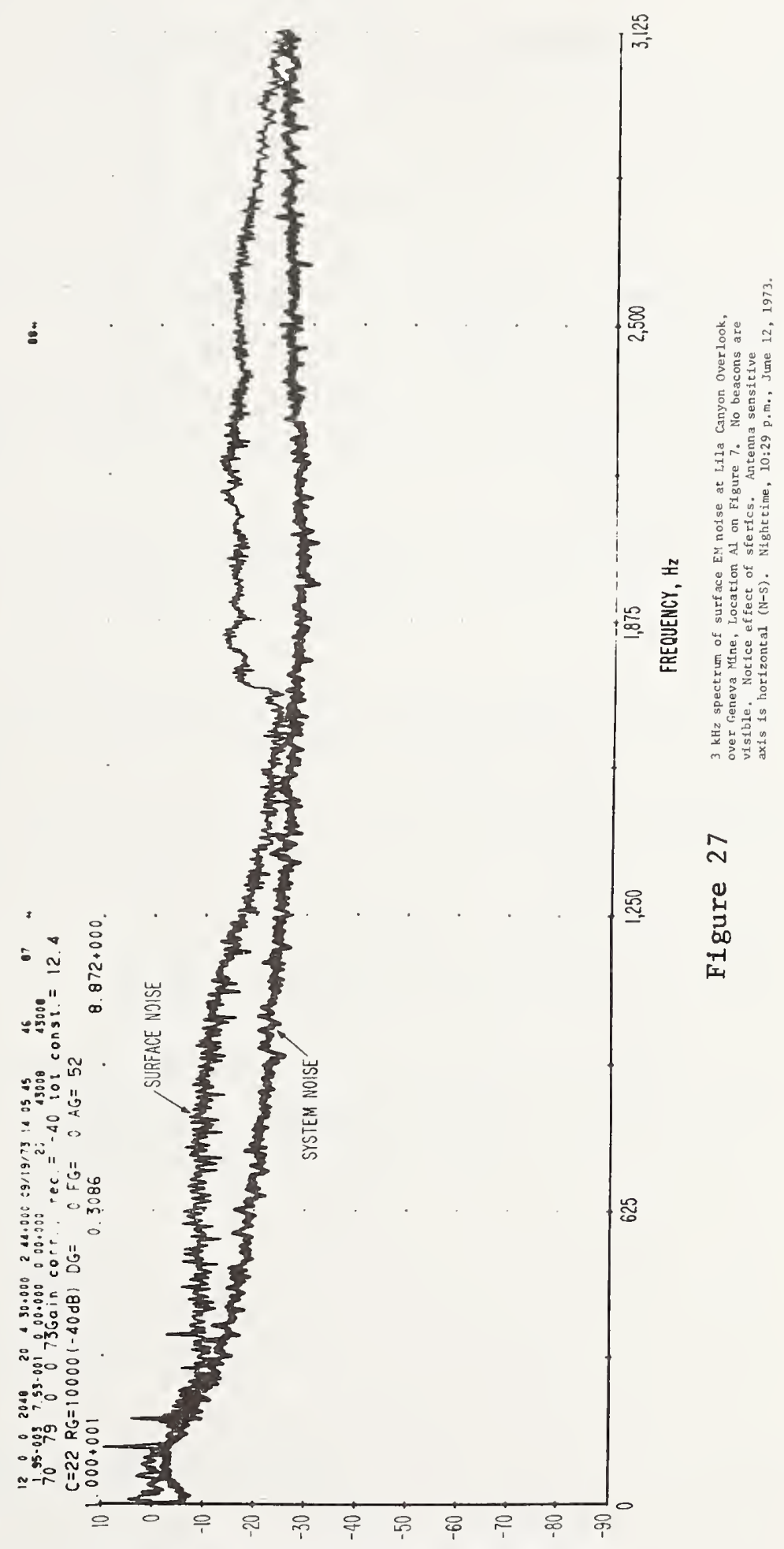

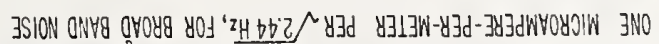

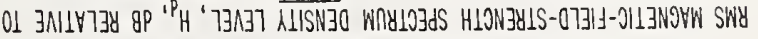

หั

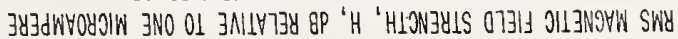




\subsection{Appendix \\ Decoding of Spectrum Captions}

Spectrum captions are generally organized into the following format:

First line: MP NDT NZS NDA NPO RC DF date, time, frame, serial, where

MP = Two's power of length of Fourier transform, example, $2^{\mathrm{MP}}$ where $\mathrm{MP}=12$

NDT = Detrending option, example, 0 (dc removed)

NZS = Restart spectral average after output, example, 0 (restarted)

$\mathrm{NDA}=$ Data segment advance increment, example, 2048

NPO = Number of spectra averaged between output calls, examp1e, 20

$\mathrm{RC}=$ Integration time in seconds per spectra, example, 0.168

$\mathrm{DF}=$ Resolution bandwidth, spectral estimate spacing in hertz, example, 62.5

Date $=$ Date of computer processing, example, 03/21/73

Time $=$ Time of computer processing, examp1e, 15:06:34

Frame $=$ Frame set number, example, 10

Serial = Film frame serial number, example, 42 .

Second 1 ine: DTA DA(1) DA(2) DA(3) NSA NRP NPP, where DTA = Detrending filter parameter $\alpha$, example, 0.00195

$\mathrm{DA}(1)=$ Detrending filter average, $\mathrm{K}=1$, example, 59.4

$\mathrm{DA}(2)=$ Detrending filter average, $K=2$, example, 0

$\operatorname{DA}(3)=$ Detrending filter average, $K=3$, example, 0

NSA $=$ Number of periodograms averaged, example, 20

$\mathrm{NRP} \quad=$ Number of data points processed since spectrum initialization, example, 43008

NPP = Number of data points processed since data initialization, example, 43008 . 
Third line: RUN, SESSION, MONTH, DAY, YEAR Gain corr., rec.= tot. constr. =, where

Run and Session = the title of the portrayed frame identifying the digitizing session and run number, example, 2183

Month, Day, Year = date data were recorded in the mine, example, 82573

Gain corr. rec. = receiver gain correction, example, -6

tot. const. = constant gain correction of entire system, example, 46.4

Fourth line: $\mathrm{C}=, \mathrm{RG}=, \mathrm{DG}=, \mathrm{FG}=, \mathrm{AG}=$, where

$\mathrm{C}=$ correction curve used with data, example, 25

$\mathrm{RG}=$ receiver gain and accompanying correction in $\mathrm{dB}$ added to the data, example, $200(-6 \mathrm{~dB})$

$\mathrm{DG}=$ digitizer gain, example, 0

$F G=$ filter gain in $d B$, often rounded to nearest single digit, example, 0

$A G=$ absolute gain correction added to data, example, 52

Fifth line: Top of Scale, Standard Error, Spectral Peak, where Top of Scale = largest scale marking for computer drawn graph, example, $1.000+004\left(1.0 \times 10^{4}\right)$

Standard Error = standard error of curve, example, 0.3162 Spectral Peak = largest spectral peak observed, example, $4.108+003\left(4.108 \times 10^{3}\right)$ 


\begin{tabular}{|c|c|c|c|}
\hline $\begin{array}{l}\text { U.S. DEPT. OF COMM. } \\
\text { BIBLIOGRAPHIC DATA } \\
\text { SHEET }\end{array}$ & $\begin{array}{l}\text { 1. PUBLICATION OR REPORT NO. } \\
\text { NBSIR } 74-369\end{array}$ & $\begin{array}{l}\text { 2. Gov't Accession } \\
\text { No. }\end{array}$ & 3. Recipient's Accession No. \\
\hline \multirow{2}{*}{\multicolumn{3}{|c|}{ SURFACE MAGNETIC-FIELD NOISE MEASUREMENTS AT GENEVA MINE }} & $\begin{array}{c}\text { 5. Publication Date } \\
6 / 74\end{array}$ \\
\hline & & & $\begin{array}{l}\text { 6. Performing Organization Code } \\
276.55\end{array}$ \\
\hline \multicolumn{3}{|c|}{$\begin{array}{l}\text { 7. AUTHOR(S) } \\
\text { J. W. Adams, W. D. Bensema, N. C. Tomoeda }\end{array}$} & 8. Performing Organ. Report No. \\
\hline \multirow{2}{*}{\multicolumn{3}{|c|}{$\begin{array}{l}\text { 9. PERFORMING ORGANIZATION NAME AND ADDRESS } \\
\text { NATIONAL BUREAU OF STANDARDS, BOUlder Labs } \\
\text { DEPARTMENT OF COMMERCE } \\
\text { WASHINGTON, D.C. } 20234\end{array}$}} & $\begin{array}{l}\text { 10. Project/Task/Work Unit No. } \\
2768412\end{array}$ \\
\hline & & & $\begin{array}{c}\text { 11. Contract/Grant No. } \\
\text { H0133005 }\end{array}$ \\
\hline \multirow{2}{*}{\multicolumn{3}{|c|}{$\begin{array}{l}\text { 12. Sponsoring Organization Name and Complete Address (Street, City, State, ZIP) } \\
\text { U. S. Bureau of Mines } \\
\text { Pittsburgh Mining and Safety Research Center } \\
4800 \text { Forbes Avenue } \\
\text { Pittsburgh, Pennsylvania }\end{array}$}} & $\begin{array}{l}\text { 13. Type of Report \& Period } \\
\text { Covered }\end{array}$ \\
\hline & & & 14. Sponsoring Agency Code \\
\hline
\end{tabular}
15. SUPPLEMENTARY NOTES

16. ABSTRACT (A 200-word or less factual summary of most significant information. If document includes a significant bibliography or literature survey, mention it here.)

Measurements of surface magnetic field noise were made at various locations over the Geneva Coal Mine near Price, Utah, on June 12, 1973. The locations selected were on the surface over emergency locator beacons underground at depths between 350 meters (1150 ft.) and 488 meters (1600 ft.). The surface terrain where these measurements were made was mountainous, and access was difficult. There were no power lines within several miles, and the weather was clear; therefore, the magnetic noise levels were about as low as will normally occur.

Results of measurements of distant sferics indicate rather sharp cutoff frequencies below which broadband, impulsive noise is at tenuated. The mechanism of propagation for this noise above the daytime cutoff frequency of $3500 \mathrm{~Hz}$ and the nighttime cutoff frequency of $1700 \mathrm{~Hz}$ is deduced to be a waveguide formed by the D or E layers of ionosphere as an upper plane and the earth as a lower plane.

The measurement systems used are similar to those used earlier. The technique is to record broadband, analog signals, digitize the data, and use a fast-Fourier transform to obtain spectral plots. This technique is novel in that it can measure simultaneously all magnetic field energy within a limited portion of the spectrum for a limited time, and, after processing, reproduce the events occurring in that time interval in great detail.

17. KEY WORDS (six to twelve entries; alphabetical order; capitalize only the first letter of the first key word unless a proper name; separated by semicolons) Earth-ionosphere waveguide; electromagnetic noise; EMI measurement technique; sferic interference.

18. AVAILABILITY

X Unlimited

For Official Distribution. Do Not Release to NTIS

Order From Sup. of Doc., U.S. Government Printing Office Washington, D.C. 20402, SD Cat. No.C13

Order From National Technical Information Service (NTIS) Springfield, Virginia 22151

\begin{tabular}{|c|c|}
\hline & $\begin{array}{l}\text { SECURITY CLASS } \\
\text { (THIS REPURT) }\end{array}$ \\
\hline & UNCL ASSIF IED \\
\hline 20. & $\begin{array}{l}\text { SECURITY CLASS } \\
\text { (THIS PAGE) }\end{array}$ \\
\hline & UNCLASSIFIED \\
\hline
\end{tabular}



S 